\title{
Provincial Financial Inclusion in Turkey: Measurement and Its Spatial Determinants
}

\author{
İbrahim BOZKURT \\ Rıfat KARAKUŞ²
}

http://orcid.org/0000-0003-4921-8767
http://orcid.org/0000-0003-3580-5207

\begin{abstract}
This present study explores the drivers affecting the provincial financial inclusion levels by using data belonging to 81 Turkish provinces during 2011 - 2016. After computing the index of financial inclusion for each province, we used spatial regression methods which control for spatial dependences because Moran's I statistic and Local Indicator of Spatial Association (LISA) analysis revealed that there are the spatial spillover and heterogeneity in provincial financial inclusion. To cope with the possible endogeneity problems, we estimated the spatial models via System GMM estimator. The findings show that "unemployment", "urban", "tourism", "married", "education", "inflation" and "crime" variables are the determinants of provincial financial inclusion for Turkey. We also detect a convergence in financial inclusion levels of provinces.
\end{abstract}

Keywords: Financial inclusion; financial inclusion index; spatial econometrics; System GMM; convergence of financial inclusion.

\section{Introduction}

With the most basic definition, financial inclusion is the reaching to and utilizing from all financial instruments needed by every segment of society. Financial inclusion concept is to involve also the necessary knowledge and skills to use financial products (Bozkurt, Karakuş \& Yıldız, 2018). Usually, to measure its level, financial inclusion indices are used (see, e.g., Wang \& Guan, 2017; Arora, 2014; Sarma, 2008; Gupte, Venkataramani \& Gupta, 2012) and these indices contain multifarious dimensions. Since financial inclusion is a multidimensional concept, it has an impact on different issues ${ }^{1}$ such as economic growth. Financial inclusion impacts economic growth primarily through two channels (Dabla-Norris et al., 2015). First, it allows funds, which are collected from all segments of the society, to be used by the more talented entrepreneurs and thus the aggregate output increases. Second, the use of more efficient financial instruments, which are developed to provide financial inclusion, also allows for increasing GDP by reducing the waste from financial frictions. The positive effect of financial inclusion on economic growth and poverty is advocated in three basic theories (see, Beck, Levine and Levkov, 2007; Marr and Schmied, 2013; Schmied and Marr, 2017; Nwafor and Yomi, 2018). According to investment theory, financial inclusion benefits the poor population, via the reduction of collateral requirements and borrowing costs. On the other hand, a decline in the collateral requirements and borrowing costs thanks to a successful financial inclusion also can unleash the entrepreneur potential of a population or might ameliorate the businesses of entrepreneurs. Human capital theory explains that people need access to credit (i.e. finance) in order to invest in their human capital which is required to find a good job and to increase their personal incomes. Finally, according to the firm-behaviour theory, financial inclusion has positive external effects on the drops in the cost of capital, which can cause an increase in production.

The aforementioned positive effects of financial inclusion on the economic system have made it an

\footnotetext{
' Assoc. Prof., Cankiri Karatekin University, Faculty of Economic and Administrative Sciences, Department of Banking and Finance, Turkey, ibozkurt@karatekin.edu.tr

${ }^{2}$ Asst. Prof., Cankiri Karatekin University, Faculty of Economic and Administrative Sciences, Department of Banking and Finance Turkey, rifatkarakus@hotmail.com
} 
important agenda item for both individual countries and international organizations. G20 Leaders confirmed a concrete Financial Inclusion Action Plan at the 2010 Seoul Summit and subsequently declared the establishment of the Global Partnership for Financial Inclusion by recognizing financial inclusion as one of the main pillars of the global development agenda (World Bank, 2014). To date, more than 60 governments across the world have also set financial inclusion as a formal target and financial inclusion was adopted as a principal purpose by the member countries of United Nations in the post-2015 Development Agenda (Sahay et. al., 2015). Financial inclusion has been internalized as a formal target in Turkey too. In Turkey as an emerging market, the Prime Ministry Mandate named "Financial Access, Financial Education, Financial Consumer Protection Strategy and Action Plans" came into effect on 05.06. 2014. This mandate, based on the principles of $G 20$ (at Toronto Summit) for Innovative Financial Inclusion, aims to spread financial products and services to all individuals and businesses, to integrate excluded people into the financial system, to increase the quality and usage of financial products and services, and ultimately, to develop financial inclusion. When action plans in the relevant mandate are examined in detail, it is seen to be focused on two important issues: (i) financial education covering the entire community and (ii) protection of consumers. Turkey has already previously focused on increasing the diversity of financial products and services with "Istanbul International Financial Center Strategy and Action Plan" prepared by the State Planning Organization of Turkey (DPT) in 2009.

Although financial inclusion is an important agenda item for countries, about 40 per cent of adults in the world does not have an account at a formal financial institution according to the 2014 Global Findex database of The World Bank. Considering regional and global averages, in emerging markets, the share of adults with an account (54\%) is a lower than the world and advanced markets with an account penetration of $62 \%$ and $94 \%$, respectively. Furthermore, emerging countries with the percentages of $40 \%$ and " $9 \%$ " fall behind the advanced countries with a formal saving percentage of $70 \%$ (among savers) and a formal credit usage of "18\%". In Turkey as an emerging market, the percentage of adults with an account at a formal financial institution is $57 \%$. Just as other emerging countries, account penetration in Turkey is still lower than the world and advanced countries, in other words, an important part $(43 \%)$ of Turkey's population is unbanked (Demirgüç-Kunt et. al., 2015). These backward indicators reveal providing insight into how to further financial inclusion is crucial for emerging markets. In this study, we will help policymakers by serving a deeper understanding about which factors are crucial for further financial inclusion in Turkey as an emerging country.

The main purpose of this paper is to measure financial inclusion levels across 81 Turkish provinces between 2011 and 2016 (i.e. calculate the financial inclusion indices) and to investigate the determinants of the financial inclusion by using spatial econometric models for Turkey. The paper is organized as follows. The next part provides an overview of the contribution of this paper to the literature. The data used for calculating the financial inclusion levels across 81 Turkish provinces and spatial models of this paper are presented in the section Data and Methodology. The last section, which follows the estimation results, is the conclusion and discussion section.

\section{Literature}

\subsection{Literature Review}

Financial inclusion has been one of the most popular topics for not only policymakers but also researchers. When analyzing the existing literature, two issues have come to the fore among scholars. One is how to measure financial inclusion level, and the other one is to identify the factors associated with it. In the growing literature, financial inclusion level is measured by using an index of financial inclusion (IFI) and IFI is calculated by considering various dimensions of the financial inclusion. For instance, three dimensions ("accessibility", "availability" and "usage") were embraced by Sarma (2008). In a study, the financial inclusion dimensions were classified again into three categories: "banking penetration", "availability of the banking services" and "usage of the banking system" (Chattopadhyay, 2011). Arora (2014) considered the dimensions named as "procedures and cost","outreach" and "ease" and Gupte, Venkataramani \& Gupta (2012) captured these basic dimensions:"penetration and accessibility","usage","ease of transactions" and "cost of transactions". Wang \& Guan (2017) calculated the IFl using two dimensions ("access" and "usage") in order to overcome biased results due to multi-collinearity among the similar dimensions such as "accessibility" and "availability" included in the related literature. Details of our IFI calculations are provided in the data and methodology section. 
As for the literature, whose aim is to determine the factors affecting financial inclusion, some of these few studies are summarized in Table 1.

Table 1: Literature Review

\begin{tabular}{|c|c|c|c|c|}
\hline Author(s) & $\begin{array}{l}\text { The Subject and Aim of } \\
\text { the Study }\end{array}$ & $\begin{array}{l}\text { Independent or } \\
\text { Control Variables }\end{array}$ & $\begin{array}{l}\text { Method of the } \\
\text { Study and } \\
\text { Variables Used }\end{array}$ & Findings \\
\hline $\begin{array}{l}\text { Wang \& } \\
\text { Guan } \\
(2017)\end{array}$ & $\begin{array}{l}\text { Financial inclusion levels } \\
\text { of the countries in the } \\
\text { worldwide in } 2011 . \\
\text { This study attempts to } \\
\text { reveal which factors } \\
\text { significantly influence } \\
\text { financial inclusion. }\end{array}$ & $\begin{array}{l}\text { Income, telephone, } \\
\text { internet, gender, } \\
\text { literacy, the ratios } \\
\text { about banking, } \\
\text { Gini coefficient, } \\
\text { unemployment, } \\
\text { poverty }\end{array}$ & $\begin{array}{l}\text { Spatial } \\
\text { Regression }\end{array}$ & $\begin{array}{l}\text { According to the results of the } \\
\text { study, the factors affecting the } \\
\text { financial inclusion levels of } \\
\text { the countries are individual's } \\
\text { income, education and use of } \\
\text { communications equipment, } \\
\text { financial depth and banking health } \\
\text { status. }\end{array}$ \\
\hline $\begin{array}{l}\text { Kairiza, } \\
\text { Kiprono \& } \\
\text { Magadzire } \\
\text { (2017) }\end{array}$ & $\begin{array}{l}\text { Financial inclusion levels } \\
\text { of the Micro, Small and } \\
\text { Medium Enterprises in } \\
\text { Zimbabwe in } 2012 . \\
\text { This study examines } \\
\text { the mutual interaction } \\
\text { between the gender } \\
\text { of entrepreneurs and } \\
\text { financial inclusion. }\end{array}$ & $\begin{array}{l}\text { Some characteristic } \\
\text { features of } \\
\text { entrepreneurs and } \\
\text { their enterprises, such } \\
\text { as gender, age, marital } \\
\text { status, education level, } \\
\text { initial capital, turnover, } \\
\text { profit and number of } \\
\text { workers. }\end{array}$ & $\begin{array}{l}\text { Tobit and OLS } \\
\text { Regression }\end{array}$ & $\begin{array}{l}\text { Some findings of the study are as } \\
\text { below: } \\
\text { (i)There is statistically weak } \\
\text { evidence of female financial } \\
\text { exclusion in the formal } \\
\text { financial sector and (ii) Female } \\
\text { entrepreneurs are no less likely } \\
\text { to be financially included in the } \\
\text { informal financial markets than } \\
\text { their male counterparts. }\end{array}$ \\
\hline $\begin{array}{l}\text { Al-Hussainy, } \\
\text { Beck, } \\
\text { Demirguc- } \\
\text { Kunt \& Zia } \\
\text { (2008) }\end{array}$ & $\begin{array}{l}\text { The usage levels of } \\
\text { financial services across } 7 \\
\text { countries. } \\
\text { This study examines } \\
\text { the effect of household } \\
\text { characteristics on the use } \\
\text { of financial services. }\end{array}$ & $\begin{array}{l}\text { Urban population, age, } \\
\text { gender, household } \\
\text { income, educational } \\
\text { status, marital status, } \\
\text { unemployment, the } \\
\text { number of people in } \\
\text { the household. }\end{array}$ & $\begin{array}{l}\text { Probit } \\
\text { Regression and } \\
\text { Panel } \\
\text { Regression }\end{array}$ & $\begin{array}{l}\text { According to the results, some } \\
\text { important variables that explain } \\
\text { the having an account are urban } \\
\text { population, age, being married } \\
\text { and being literate. In addition, } \\
\text { having a bank loan is positively } \\
\text { correlated with urban dwellings, } \\
\text { household size, and being married. }\end{array}$ \\
\hline $\begin{array}{l}\text { Fungáčová } \\
\text { \&Weill } \\
(2015)\end{array}$ & $\begin{array}{l}\text { Financial inclusion levels } \\
\text { of China and the other } \\
\text { BRICS in2011. } \\
\text { This study analyzes } \\
\text { the financial inclusion } \\
\text { and determinants of its } \\
\text { indicators. }\end{array}$ & $\begin{array}{l}\text { Income, education, age, } \\
\text { gender. }\end{array}$ & $\begin{array}{l}\text { Probit } \\
\text { Regression }\end{array}$ & $\begin{array}{l}\text { According to the results; higher } \\
\text { income, better education, being } \\
\text { a man, and being older are } \\
\text { associated with greater use of } \\
\text { formal accounts and formal credit } \\
\text { in China. }\end{array}$ \\
\hline $\begin{array}{l}\text { Zins \& Weill } \\
\text { (2016) }\end{array}$ & $\begin{array}{l}\text { Financial inclusion levels } \\
\text { of } 37 \text { African countries. } \\
\text { This study examines the } \\
\text { determinants of financial } \\
\text { inclusion. }\end{array}$ & $\begin{array}{l}\text { Gender, age, income, } \\
\text { education. }\end{array}$ & $\begin{array}{l}\text { Probit } \\
\text { Regression }\end{array}$ & $\begin{array}{l}\text { Authors find that being a man, } \\
\text { richer, more educated and older } \\
\text { to a certain extent favour financial } \\
\text { inclusion. }\end{array}$ \\
\hline
\end{tabular}




\begin{tabular}{|c|c|c|c|c|}
\hline Author(s) & $\begin{array}{l}\text { The Subject and Aim of } \\
\text { the Study }\end{array}$ & $\begin{array}{l}\text { Independent or } \\
\text { Control Variables }\end{array}$ & $\begin{array}{l}\text { Method of the } \\
\text { Study and } \\
\text { Variables Used }\end{array}$ & Findings \\
\hline $\begin{array}{l}\text { Sahoo, } \\
\text { Pradhan \& } \\
\text { Sahu } \\
(2017)\end{array}$ & $\begin{array}{l}\text { Financial inclusion levels } \\
\text { of the tribal people in } \\
\text { Odisha state in India for } \\
2013 . \\
\text { This study investigates } \\
\text { the various determinants } \\
\text { of financial inclusion of } \\
\text { tribal households. }\end{array}$ & $\begin{array}{l}\text { Income, education, } \\
\text { possession of private } \\
\text { land, distance. }\end{array}$ & Logit Regression & $\begin{array}{l}\text { According to the results; some } \\
\text { important determinants of tribal } \\
\text { financial participation are years of } \\
\text { education obtained by the head of } \\
\text { household, size of privately-owned } \\
\text { land and total annual income of } \\
\text { the household. }\end{array}$ \\
\hline $\begin{array}{l}\text { Honohan } \\
\text { (2008) }\end{array}$ & $\begin{array}{l}\text { The access levels to } \\
\text { financial services of the } \\
\text { countries around the } \\
\text { world. } \\
\text { This study investigates } \\
\text { the relationship between } \\
\text { financial access and } \\
\text { country characteristics. }\end{array}$ & $\begin{array}{l}\text { GNI, age, birth rate, } \\
\text { population, population, } \\
\text { mobile phone } \\
\text { subscribers, illiteracy, } \\
\text { inflation, institutions. }\end{array}$ & Regression & $\begin{array}{l}\text { According to the results; higher } \\
\text { mobile phone penetration and } \\
\text { better institutions of governance } \\
\text { are correlated across countries } \\
\text { with the new access series. }\end{array}$ \\
\hline $\begin{array}{l}\text { Chithra \& } \\
\text { Selvam } \\
(2013)\end{array}$ & $\begin{array}{l}\text { Financial inclusion index } \\
\text { scores of the states in } \\
\text { India. } \\
\text { This study analyzes the } \\
\text { determinants of financial } \\
\text { inclusion. }\end{array}$ & $\begin{array}{l}\text { Rural population, } \\
\text { unemployment, } \\
\text { income, literacy, } \\
\text { internet, phone, road, } \\
\text { computer. }\end{array}$ & Regression & $\begin{array}{l}\text { According to the results, the socio- } \\
\text { economic factors, income, literacy } \\
\text { and population have a significant } \\
\text { association with the level of } \\
\text { financial inclusion. }\end{array}$ \\
\hline $\begin{array}{l}\text { Andrianaivo } \\
\& \text { Kpodar } \\
(2011)\end{array}$ & $\begin{array}{l}\text { Financial inclusion levels } \\
\text { of the selected African } \\
\text { countries from } 1988 \\
\text { through } 2007 . \\
\text { In a part of this paper, } \\
\text { authors investigate the } \\
\text { determinants of financial } \\
\text { inclusion. }\end{array}$ & $\begin{array}{l}\text { Mobile phone, GDP, } \\
\text { population density, } \\
\text { the quality of the } \\
\text { legal environment, } \\
\text { geographical coverage } \\
\text { of bank branches. }\end{array}$ & Regression & $\begin{array}{l}\text { According to the results; mobile } \\
\text { phone development is strongly } \\
\text { positively correlated to financial } \\
\text { inclusion and better coverage of } \\
\text { bank branches enhance financial } \\
\text { inclusion. }\end{array}$ \\
\hline $\begin{array}{l}\text { Kendall, } \\
\text { Mylenko \& } \\
\text { Ponce } \\
\text { (2010) }\end{array}$ & $\begin{array}{l}\text { Financial access } \\
\text { indicators for countries } \\
\text { across the globe in } 2008 . \\
\text { Authors analyze the } \\
\text { determinants of the } \\
\text { financial access indicator. }\end{array}$ & $\begin{array}{l}\text { GDP, population, } \\
\text { inflation, Gini, phone } \\
\text { lines, road lines, } \\
\text { absence of violence }\end{array}$ & Regression & $\begin{array}{l}\text { According to the results; authors } \\
\text { find significant associations of } \\
\text { deposit and loan penetration } \\
\text { with per capita income, physical } \\
\text { and financial infrastructure, and } \\
\text { macroeconomic stability. }\end{array}$ \\
\hline $\begin{array}{l}\text { Uddin, } \\
\text { Chowdhury, } \\
\text { \& Islam } \\
\text { (2017) }\end{array}$ & $\begin{array}{l}\text { Financial inclusion level } \\
\text { of Bangladesh during the } \\
\text { period 2005-2014. } \\
\text { This paper is to identify } \\
\text { the factors that determine } \\
\text { the level of financial } \\
\text { inclusion in Bangladesh }\end{array}$ & $\begin{array}{l}\text { Bank size, interest rate, } \\
\text { GNI, inflation, literacy, } \\
\text { age }\end{array}$ & $\begin{array}{l}\text { Dynamic GMM } \\
\text { and Quantile } \\
\text { Regression }\end{array}$ & $\begin{array}{l}\text { The empirical findings suggest } \\
\text { that literacy rate is positively and } \\
\text { age dependency ratio is negatively } \\
\text { related to financial inclusion. Also, } \\
\text { bank size has a significant impact } \\
\text { on both deposit collection and } \\
\text { loans. }\end{array}$ \\
\hline $\begin{array}{l}\text { Bozkurt, } \\
\text { Karakuş \& } \\
\text { Yıldız } \\
\text { (2018). }\end{array}$ & $\begin{array}{l}\text { Financial inclusion levels } \\
\text { of the countries in the } \\
\text { worldwide for } 2011 \text { and } \\
2014 \text {. } \\
\text { Authors investigate the } \\
\text { spatial determinants of } \\
\text { financial inclusion. }\end{array}$ & $\begin{array}{l}\text { Age, population, urban, } \\
\text { GNI, unemployment, } \\
\text { education, internet, } \\
\text { phone, political factors, } \\
\text { banking factors }\end{array}$ & $\begin{array}{l}\text { Spatial } \\
\text { Regression }\end{array}$ & $\begin{array}{l}\text { According to the results; social, } \\
\text { banking and political factors } \\
\text { play an important role in the } \\
\text { determination of change in } \\
\text { financial inclusion. }\end{array}$ \\
\hline
\end{tabular}


Table 1 provides an overview of the studies, which examined the determinants of financial inclusion. When the studies in the literature are examined, the contributions of our paper to literature are discussed below.

\subsection{Contribution to the Literature}

The focal point of this paper is Turkey as an emerging market. Though there are few studies on the determinants of financial inclusion in the emerging countries such as Africa (Zins and Weill, 2016), China (Fungácová and Weill, 2015), Bangladesh (Siddik, Sun and Kabiraj, 2015) and India (Kumar, 2013; Chithra and Selvam, 2013; Yadav and Sharma, 2016), as far as we know, we focus on Turkey for the first time. This paper contributes to the literature not just because Turkey is an emerging market but also because Turkey is a Muslim ${ }^{2}$ and candidate country wishing to join the European Union (EU). As is known, candidate countries need to be close to EU standards in many issues such as social, political and economic. If Turkey can boost its financial inclusion level ${ }^{3}$, it can get close enough to the social and economic standards of the EU because of the abovementioned possible positive effects ${ }^{4}$ of financial inclusion. Therefore, to apperceive the factors affecting financial inclusion is important for Turkey to collaborate with the EU. As regards Turkey's religious structure, the Muslim population in a country can be excluded from the financial system because they are against the interest (see, Mohieldin, lqbal, Rostom and Fu, 2011). Demirgüç-Kunt et al. (2013) find that Muslims resort significantly less to formal account than non-Muslims. In this respect too, it will be again interesting to concentrate on Turkey. We believe that this paper is remarkable and useful for researchers and policymakers because we, in this study, decipher the factors explaining the financial inclusion level in a Muslim candidate country to the EU.

Although Yorulmaz (2013) previously has calculated provincial IFI scores of Turkey for the years 2004 through 2010 by using three dimensions (penetration, availability and usage); we, in analogy to Wang \& Guan (2017), calculated the IFI by using two dimensions ("access" and "usage") in order to overcome biased results due to multi-collinearity among the similar dimensions. We, for the first time, compute the IFI scores between 2011 and 2016 years for Turkish provinces with this approach. Here, the determination of the IFI scores for more than one period enables us to decipher the factors influencing the IFI scores over time.
In the recent few studies, Wang \& Guan (2017) and Bozkurt, Karakuş and Yıldız (2018) employed spatial regression models to define the drivers affecting financial inclusion throughout the world. This paper, however, employs spatial panel models in order to investigate the determinants of provincial IFI scores in Turkey by considering the role of spatial interactions on financial inclusion.

We also detect a convergence in the distribution of provincial IFI scores in Turkey due to the positive spillover effects of financial inclusion. This detection enabled us to offer policy implications on how to attenuate the disparity in the provincial financial inclusion level of Turkey. Furthermore, thanks to this detection, this issue can draw more attention from scholars in the future.

Finally, we (apart from empirical literature) used some novel variables such as "crime rate" and "tourism" (see, section "data and methodology").

\section{Data and Methodology}

\subsection{Index of Financial Inclusion (IFI)}

The graphical presentation of calculating the IFI for a province is presented in Fig. 1. As is also understood from Fig. 1, we, in analogy to Wang \& Guan (2017) and Bozkurt, Karakuş \& Yıldız (2018), considered two major dimensions ("access" and "usage" of financial services) when calculating the IFI scores across 81 Turkish provinces.

The IFI scores for 81 provinces in Turkey are calculated in two steps by utilizing from the data of the Statistical Reports of The Banks Association of Turkey. For each province, the first stage is to generate and calculate the dimension indexes and the second stage is to compute the IFI scores by combining the related dimension indexes ${ }^{5}$. This computing algorithm of IFI, which is proposed by Wang \& Guan (2016), is given in detail in Eq. 1, 2, 3 and 4.

In the Eq. 1, " $x$ " is the converted value of indicator $j$ (where j runs from 1 to $n$ ) for each province $k$. To convert the indicator values, which are differed in terms of the measurement and size, into the new values the range from 0 to 1, minimum and maximum values were stated and then Eq. 2 was implemented. " $w$ " is the weight of each indicator $j$. The weight of an indicator $j$ within dimension "I" was calculated, by Eq. 3, as the ratio of variation coefficient of the converted values in the indicator $j$ to the total of the variation coefficients of all indicators within dimension "I". Following computed 
the dimension indexes by Eq. 1 ; IFI of each province is generated by Eq. 4 as the weighted mean of normalized access and usage indexes. In the Eq. 4, " $w$ "is the weight of each dimension "I" (where "I" runs from 1 to 2 ) and was calculated as the ratio of the sum of the variation coefficients of all indicators in the related dimension to the sum of the variation coefficients of all indicators within both dimension. The summary of all indicators in Fig. 1 is presented in Appendix A.

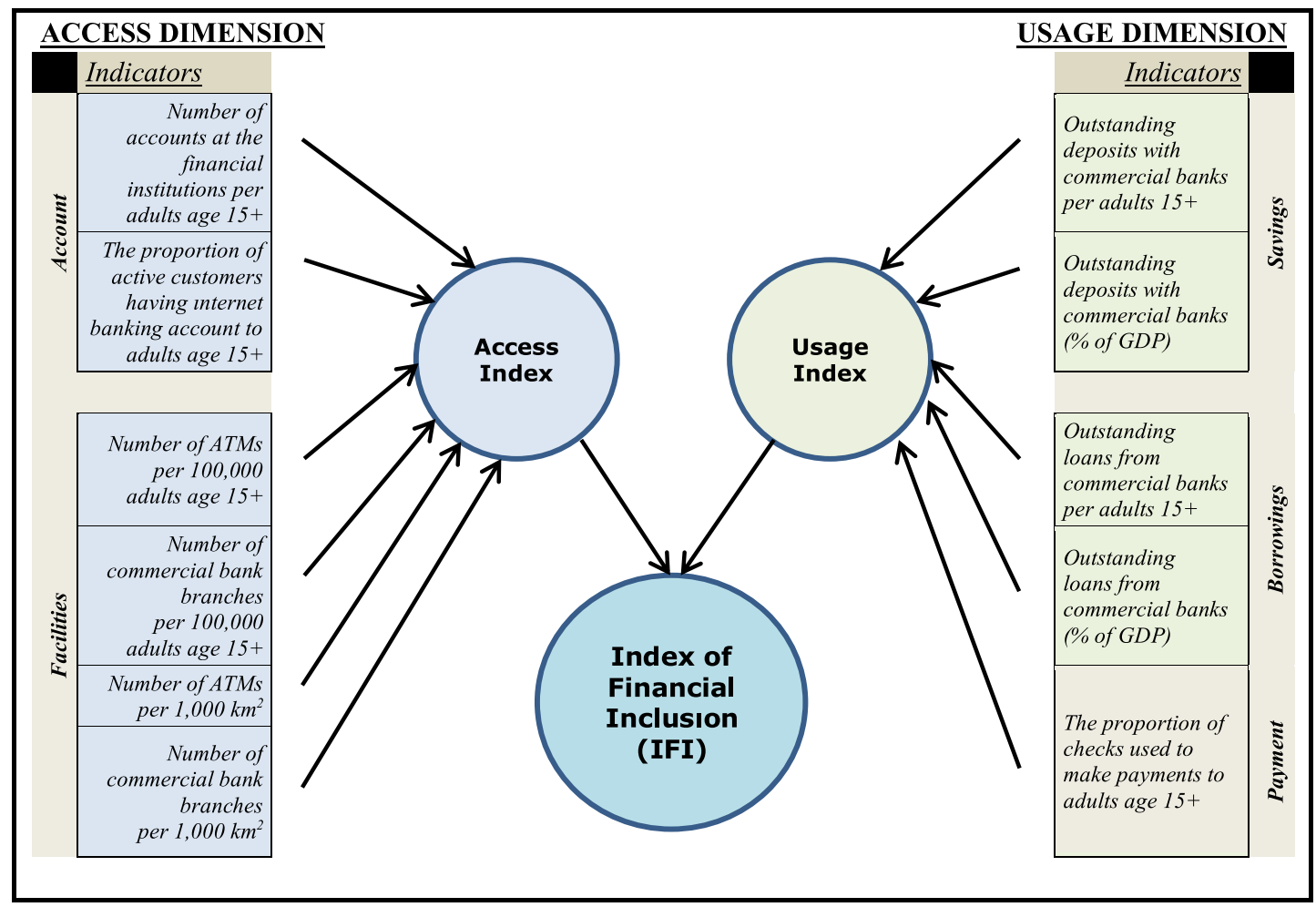

Figure 1: Calculating the Index of Financial Inclusion

Index of Dimension I for Province $\mathrm{k}=1-\frac{\sqrt{w_{I 1}^{2}\left(1-x_{I 1}\right)^{2}+w_{I 2}^{2}\left(1-x_{I 2}\right)^{2}+\ldots .+w_{I n}^{2}\left(1-x_{I n}\right)^{2}}}{\sqrt{\left(w_{I 1}^{2}+w_{I 2}^{2}+\ldots .+w_{I n}^{2}\right)}}$

$\mathrm{x}_{j}$ for province $\mathrm{k}=\frac{\text { Actual Value of Province } \mathrm{k}_{j} \text { - Minimum Value }}{\text { Maximum Value }_{j}-\text { Minimum Value }_{j}}$

${ }^{\mathrm{w}_{I j}}=\frac{\text { Coefficient of Variation }_{I j}}{\sum_{j} \text { Coefficient of Variation }}$

IFI for Province $\mathrm{k}=1-\frac{\sqrt{w_{\text {Access Index }}^{2}(1-\text { Access Index })^{2}+w_{\text {Usage Index }}^{2}(1-\text { Usage Index })^{2}}}{\sqrt{\left(w_{\text {Access Index }}^{2}+w_{\text {Usage Index }}^{2}\right)}}$

Table 2 exhibits the IFI scores of 81 Turkish provinces during 2011-2016 ${ }^{6}$. According to Table 2, seven of the top ten provinces are the cities (Istanbul, Izmir, Kocaeli, Bursa, Aydın, Muğla and Yalova) in the west of Turkey and Istanbul is the city with the highest IFI score for all years. Ankara in the top ten is a province located in central of Turkey while Gaziantep is in the southern east and Antalya is in the southern west of Turkey. All of the last ten is the cities in the east which have the average IFI under the value 0.10 . 
Table 2: Provincial IFI Scores in Turkey

\begin{tabular}{|c|c|c|c|c|c|c|c|c|c|c|c|c|c|c|c|}
\hline Rank & $\begin{array}{l}\text { Province } \\
\text { Name }\end{array}$ & 2011 & 2012 & 2013 & 2014 & 2015 & 2016 & Rank & Province Name & 2011 & 2012 & 2013 & 2014 & 2015 & 2016 \\
\hline 1 & İstanbul & 945 & 0.938 & 0.941 & 0.951 & 0.968 & 0.979 & 42 & Bilecik & 0.206 & 0.200 & 0.197 & 0.200 & 0.189 & 0.190 \\
\hline 2 & İzmir & .899 & 0.867 & 0.884 & 0.871 & 0.833 & 0.850 & 43 & Kırşehir & 0.165 & 0.160 & 0.177 & 0.188 & 0.179 & 0.183 \\
\hline 3 & Kocaeli & 747 & 0.756 & 0.735 & 0.715 & 0.716 & 0.712 & 44 & Çorum & 0.175 & 0.168 & 0.183 & 0.186 & 0.182 & 0.176 \\
\hline 4 & Ankara & 718 & 0.706 & 0.698 & 0.698 & 0.704 & 0.699 & 45 & Aksaray & 0.160 & 0.152 & 0.171 & 0.174 & 0.182 & 0.174 \\
\hline 5 & Bursa & 0.585 & 0.584 & 0.572 & 0.573 & 0.578 & 0.594 & 46 & Sinop & 0.183 & 0.184 & 0.184 & 0.185 & 0.171 & 0.173 \\
\hline 6 & Yalova & 0.540 & 0.564 & 0.537 & 0.525 & 0.545 & 0.555 & 47 & Osmaniye & 0.132 & 0.148 & 0.148 & 0.153 & 0.164 & 0.171 \\
\hline 7 & Antalya & 488 & 0.482 & 0.495 & 0.497 & 0.498 & 0.492 & 48 & Kırıkkale & 0.161 & 0.170 & 0.162 & 0.167 & 0.163 & 0.169 \\
\hline 8 & Gaziantep & 373 & 0.370 & 0.406 & 0.421 & 0.425 & 0.437 & 49 & Karaman & 0.153 & 0.143 & 0.167 & 0.164 & 0.162 & 0.169 \\
\hline 9 & Aydın & 0.405 & 0.392 & 0.395 & 0.401 & 0.407 & 0.420 & 50 & Tunceli & 0.174 & 0.168 & 0.173 & 0.169 & 0.173 & 0.164 \\
\hline 10 & Muğla & 0.435 & 0.420 & 0.423 & 0.425 & 0.418 & 0.416 & 51 & Malatya & 0.146 & 0.151 & 0.157 & 0.168 & 0.162 & 0.158 \\
\hline 11 & Tekirdağ & 0.395 & 0.397 & 0.413 & 0.409 & 0.399 & 0.410 & 52 & Kütahya & 0.156 & 0.170 & 0.156 & 0.157 & 0.154 & 0.157 \\
\hline 12 & Sakarya & 371 & 0.386 & 0.374 & 0.368 & 0.378 & 0.387 & 53 & Kastamonu & 0.169 & 0.161 & 0.159 & 0.160 & 0.164 & 0.156 \\
\hline 13 & Hatay & 0.366 & 0.366 & 0.380 & 0.385 & 0.370 & 0.377 & 54 & Sivas & 0.145 & 0.155 & 0.148 & 0.154 & 0.149 & 0.154 \\
\hline 14 & Adana & 373 & 0.379 & 0.381 & 0.382 & 0.370 & 0.365 & 55 & Kilis & 0.112 & 0.119 & 0.128 & 0.132 & 0.158 & 0.153 \\
\hline 15 & Denizli & 324 & 0.302 & 0.342 & 0.349 & 0.349 & 0.356 & 56 & Elazığ & 143 & 0.144 & 0.149 & 0.164 & 0.157 & 153 \\
\hline 16 & Trabzon & 0.347 & 0.329 & 0.339 & 0.338 & 0.333 & 0.341 & 57 & Çankırı & 0.142 & 0.130 & 0.132 & 0.145 & 0.142 & 0.152 \\
\hline 17 & Zonguldak & 373 & 0.369 & 0.355 & 0.350 & 0.337 & 0.328 & 58 & Kahramanmaraş & 0.118 & 0.115 & 0.138 & 0.142 & 0.139 & 0.150 \\
\hline 18 & & & 0.30 & & & & & & & & & & & & \\
\hline 19 & Rize & 0.295 & 0.309 & 0.293 & 0.288 & 0.290 & 0.299 & 60 & Yozgat & 0.121 & 0.140 & 0.134 & 0.142 & 0.134 & 0.141 \\
\hline 20 & Edirne & 296 & 0.297 & 0.305 & 0.307 & 0.299 & 0.298 & 61 & Tokat & 0.152 & 0.139 & 0.147 & 0.148 & 0.142 & 0.139 \\
\hline 21 & Balıkesir & 300 & 0.292 & 0.296 & 0.294 & 0.291 & 0.294 & 62 & Erze & 0.124 & 0.138 & 0.127 & 0.126 & 0.130 & \\
\hline 22 & Samsun & 0.288 & 0.283 & 0.296 & 0.299 & 0.289 & 0.292 & 63 & Niğd & 0.139 & 0.137 & 0.138 & 0.141 & 0.139 & 0.135 \\
\hline 23 & Eskişehir & 287 & 0.293 & 0.301 & 0.299 & 0.297 & 0.292 & 64 & Ardahan & 0.096 & 0.081 & 0.110 & 0.116 & 0.113 & 0.121 \\
\hline 24 & Mersin & 288 & 0.295 & 0.299 & 0.298 & 0.293 & 0.285 & 65 & lğdır & 0.095 & 0.101 & 0.113 & 0.126 & 0.117 & 0.120 \\
\hline 25 & Kayseri & 265 & 0.265 & 0.276 & 0.281 & 0.268 & 0.280 & 66 & Diyarbakır & 0.101 & 0.116 & 0.106 & 0.111 & 0.109 & 0.109 \\
\hline 26 & Kırklareli & 0.262 & 0.253 & 0.257 & 0.264 & 0.257 & 0.257 & 67 & Kars & 0.092 & 0.087 & 0.100 & 0.103 & 0.104 & 0.105 \\
\hline 27 & Çanakkale & 0.242 & 0.239 & 0.235 & 0.241 & 0.243 & 0.251 & 68 & Bayburt & 0.121 & 0.134 & 0.115 & 0.109 & 0.127 & 0.096 \\
\hline 28 & Bartın & 0.264 & 0.250 & 0.254 & 0.256 & 0.252 & 0.251 & 69 & Adıyaman & 0.076 & 0.076 & 0.080 & 0.090 & 0.093 & 0.094 \\
\hline 29 & Isparta & 0.231 & 0.226 & 0.226 & 0.222 & 0.213 & 0.249 & 70 & Batman & 0.090 & 0.107 & 0.087 & 0.091 & 0.089 & 0.084 \\
\hline 30 & Manisa & 0.237 & 0.244 & 0.231 & 0.234 & 0.238 & 0.249 & 71 & Mardin & 0.064 & 0.086 & 0.075 & 0.075 & 0.080 & 0.083 \\
\hline 31 & Uşak & 0.241 & 0.230 & 0.252 & 0.259 & 0.250 & 0.244 & 72 & Gümüşhane & 0.100 & 0.092 & 0.103 & 0.098 & 0.093 & 0.082 \\
\hline 32 & Nevşehir & 0.239 & 0.241 & 0.246 & 0.254 & 0.250 & 0.241 & 73 & Siirt & 0.054 & 0.073 & 0.066 & 0.068 & 0.067 & 0.066 \\
\hline 33 & Düzce & .219 & 0.224 & 0.220 & 0.223 & 0.223 & 0.221 & 74 & Bitlis & 0.069 & 0.094 & 0.069 & 0.064 & 0.064 & 0.066 \\
\hline 34 & Konya & 0.198 & 0.213 & 0.207 & 0.212 & 0.211 & 0.217 & 75 & Şanlıurfa & 0.047 & 0.065 & 0.056 & 0.058 & 0.056 & 0.058 \\
\hline 35 & Giresun & 0.211 & 0.211 & 0.201 & 0.208 & 0.202 & 0.205 & 76 & Hakkâri & 0.047 & 0.049 & 0.046 & 0.049 & 0.045 & 0.056 \\
\hline 36 & Ordu & 0.206 & 0.202 & 0.200 & 0.207 & 0.198 & 0.202 & 77 & Van & 0.050 & 0.056 & 0.043 & 0.054 & 0.054 & 0.056 \\
\hline 37 & Amasya & 0.201 & 0.206 & 0.201 & 0.210 & 0.202 & 0.199 & 78 & Bingöl & 0.038 & 0.042 & 0.039 & 0.039 & 0.045 & 0.048 \\
\hline 38 & Bolu & 0.212 & 0.224 & 0.208 & 0.205 & 0.207 & 0.197 & 79 & Ağrı & 0.033 & 0.032 & 0.037 & 0.038 & 0.047 & 0.042 \\
\hline 39 & Burdur & 0.212 & 0.209 & 0.204 & 0.199 & 0.201 & 0.196 & 80 & Şırnak & 0.060 & 0.073 & 0.057 & 0.049 & 0.055 & 0.041 \\
\hline 40 & Afyonkarahisar & 0.183 & 0.168 & 0.180 & 0.188 & 0.186 & 0.191 & 81 & Muş & 0.012 & 0.025 & 0.016 & 0.017 & 0.020 & 0.022 \\
\hline 41 & Artvin & 0.191 & 0.183 & 0.189 & 0.194 & 0.191 & 0.190 & & Average & 0.235 & 0.236 & 0.238 & 0.240 & 0.238 & 0.244 \\
\hline
\end{tabular}

Notes:

1) The provinces are ranked with respect to IFI scores in 2016. An IFI value of 1 signifies a perfect financial inclusion level and 0 a terrible financial inclusion level. 2) Average = The mean of IFI values belonging to 81 Turkish provinces.

Looking at Table 2, at the first blush, we can see two things. First, the provinces in the highest (lowest) IFI category are generally high (low) income provinces. Second, the provinces with similar IFI values are clustered geographically (also see, Fig. 2). The first column in Fig. 2 details the spatial distributions of IFI values? ${ }^{7}$. Central Anatolia region (except; Ankara, Eskişehir and Kayseri which are in the high IFI class, and Niğde, Yozgat and Çankırı which are in the low IFI class) and its west are generally in the medium IFI class during 2011 to 2016. The low-IFI provinces are spatially aggregated in the eastern region of Turkey; however, the provinces with high IFI scores are generally clustered in Marmara region as well as in the both the western and the southern 
coastal regions of Turkey. Furthermore, the port cities in the Black Sea coast (such as Rize, Trabzon, Samsun, Zonguldak and Bartın) have also high IFI scores. When considering that the most cities in the western and southern coastal regions are major tourism cities and the port cities in the Black Sea coast have a large commercial volume, it can be alleged that high financial inclusion is associated with good economic conditions.

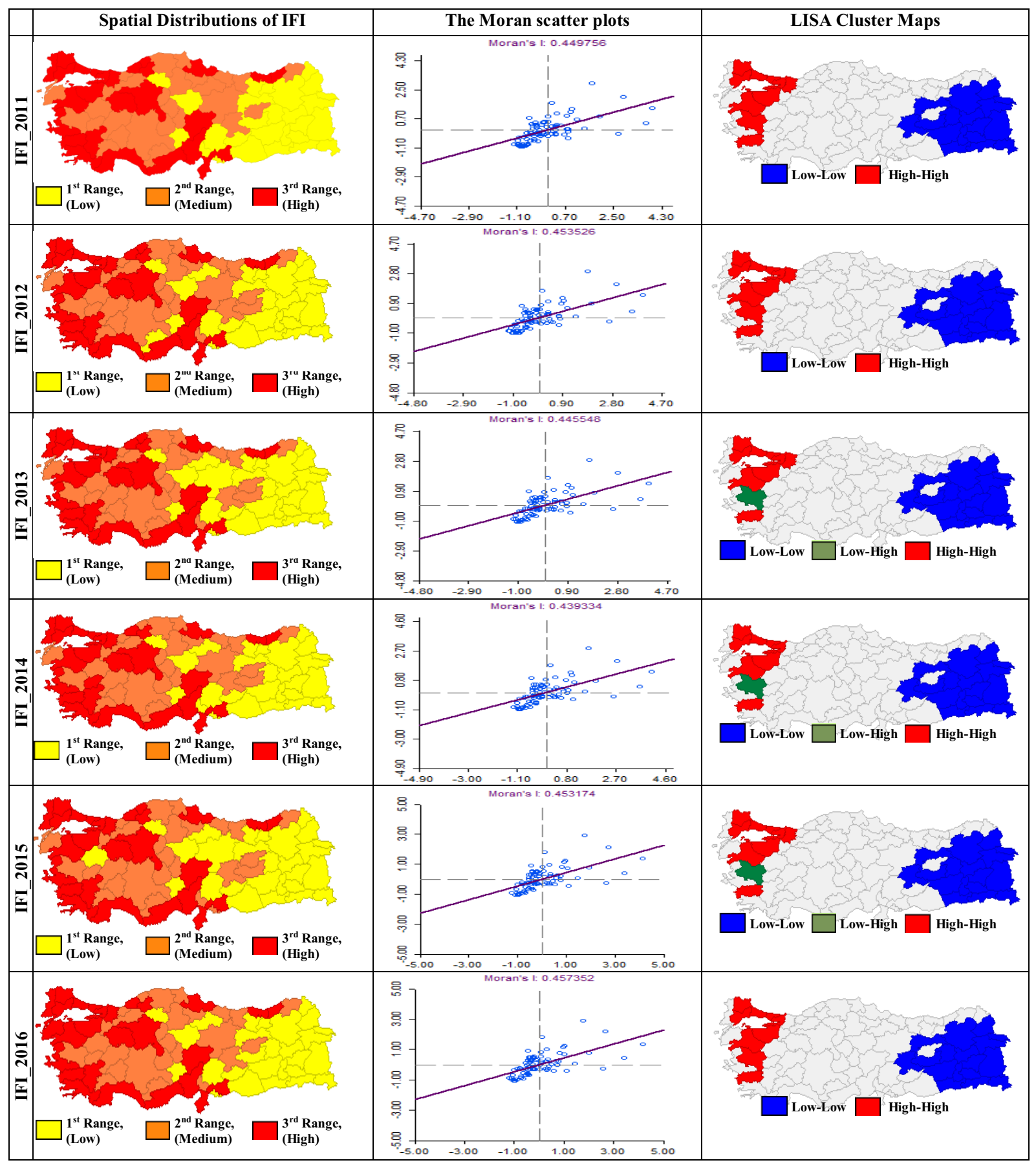

Figure 2: Geographic Distributions and Spatial Statistics of Provincial IFI Scores 


\subsection{Methodology}

The empirical analyses are fulfilled with annual IFI values of 81 Turkish provinces for 2011-2016 periods by employing spatial panel data models. Spatial panel data models are more illuminating than the mainstream panel model (Elhorst, 2010). One of the advantages of the spatial panel models is that it can be used even if the assumptions of classical panel models are invalid. The other advantage of it is to create more robust estimates thanks to controlling the spatial interdependency and heterogeneity. As it will be revealed in the next section, we detect strong spatial spillover effects and heterogeneities in our IFI data during 2011 and 2016 and so we utilize spatial panel data models in order to manifest what factors have an impact on provincial financial inclusion in Turkey.

There are different spatial panel models. These are Spatial-Autoregressive model (SAR or SLM) in Eq. 5, Spatial error model (SEM) in Eq. 6, Spatial Durbin Model (SDM) in Eq.7 and Spatial-Autoregressive with Spatially Autocorrelated Errors model (SACM) in Eq. 8.

$$
\begin{aligned}
& \log \left(I F I_{i t}\right)=\rho \sum_{j=1}^{n} W_{i j} \log \left(I F I_{i t}\right)+\sum_{k=1}^{K} \beta_{k} \log \left(X_{k i t}\right)+\varepsilon_{i t} \\
& \log \left(I F I_{i t}\right)=\sum_{k=1}^{K} \beta_{k} \log \left(X_{k i t}\right)+\lambda \sum_{j=1}^{n} W_{i j} v_{i t}+\varepsilon_{i t} \\
& \log \left(I F I_{i t}\right)=\rho \sum_{j=1}^{n} W_{i j} \log \left(I F I_{i t}\right)+\sum_{k=1}^{K} \beta_{k} \log \left(X_{k i t}\right)+\sum_{j=1}^{n} \sum_{k=1}^{K} W_{i j} \theta_{k} \log \left(X_{k i t}\right)+\varepsilon_{i t} \\
& \log \left(I F I_{i t}\right)=\rho \sum_{j=1}^{n} W_{i j} \log \left(I F I_{i t}\right)+\sum_{k=1}^{K} \beta_{k} \log \left(X_{k i t}\right)+\lambda \sum_{j=1}^{n} W_{i j} v_{i t}+\varepsilon_{i t}
\end{aligned}
$$

In the equations 5, 6, 7 and 8, "i" refers to the provinces; " $t$ " represents the period from 2011 to 2016;"log" indicates the logarithm of variables; IFI expresses the annual IFI scores for 81 provinces; $X$ is an $n \times k$ matrix of explanatory variables; " $\varepsilon$ " is error term and; $W_{i j}$ is the spatial weight matrix, which is established according to the concept of Queen Contiguity (Lesage, 1999), rendering relations of proximity between provinces "i" and " $\mathrm{j}$ ". $\sum_{i=1}^{n} W_{i j} \log \left(I F I_{i i}\right)$ is a spatially lagged dependent variable and parameter $\rho$ depict the direct spatial spillover effect of IFI scores. $\sum_{i=1}^{n} W_{i j} v_{i t}$ is spatially correlated error term and parameter $\lambda$ depicts the spillover effect between the unobserved provincial characteristics that may influence the IFI scores. Finally $\theta_{k} \sum_{i=k}^{n} \sum_{k=1}^{K} W_{i j} \log \left(X_{k i t}\right)$ is a spatially weighted explanatory variable and parameter $\theta$ reflects the effects of average-neighbour values of the explanatory variables. On the other hand, $\sum_{i=1}^{n} W_{i j} \log \left(I F I_{i i}\right)$ controls spatial connections between dependent variables, $\sum_{j=1}^{n} W_{i j} v_{i t}$ controls a possible spatial autocorrelation in error terms, and $\theta_{k} \sum_{j=1}^{n} \sum_{k=1}^{K} W_{i j} \log \left(X_{k i t}\right)$ controls spatial interdependencies between independent variables in order to attain robust findings on the spatial determinants of financial inclusion.

\subsection{Other Variables}

In this paper, we made an effort to use the independent variables in the related empirical literature (see, Table 1). However, due to the impossibility of obtaining the data related to the variables in the literature, we only used the variables available for 81 Turkish provinces. Also, we (apart from empirical literature) used two novel variables such as "crime rate" and "tourism". Carrillo-Hidalgo \& Pulido-Fernández (2019) state that the growth of tourism has stagnated in financially excluded areas and international financial institutions advocate the promotion of tourism in the fight against financial exclusion. We also take into account the variable "crime rate". Crime rate may affect positively financial inclusion. Arun \& Kamath (2015) emphasize that lower crime rate hinders the usage of the payment products (i.e. financial inclusion) and increases cash preference. For the variable of "crime rate", which denotes the ratio of convicts received into prison by type of crime to the adult population, we considered some selected types of crime (exaction, robbery, damage to property, threat and hurting) and excluded the type of swindle crime. Because this crime type includes both digital and non-digital crimes and it has a bilateral effect on IFI. For example, while non-digital swindle is expected to affect positively the usage of payment products, the digital swindle is expected to affect negatively it.

The descriptive statistics and explanations of all explanatory variables in this paper are reported in Table 3. 
Table 3: Explanatory Variables

\begin{tabular}{|c|c|c|c|c|c|}
\hline Variable & Description & Mean & SD & Min & Max \\
\hline GDP & Log of GDP per capita. & 4.255 & 0.168 & 3.786 & 4.725 \\
\hline Poverty & Log of poverty rate (by $60 \%$ of the median income). & 1.233 & 0.063 & 1.012 & 1.374 \\
\hline Unemployment & Log of unemployment rate as \% of total labor force. & 0.908 & 0.182 & 0.393 & 1.505 \\
\hline Inflation & Log of inflation rate. & 0.912 & 0.086 & 0.707 & 1.081 \\
\hline Tourism & Log of the average number of overnights of foreign tourists. & 4.137 & 1.249 & 0 & 7.797 \\
\hline Female & Log of female population rate as \% of population. & 1.695 & 0.009 & 1.623 & 1.707 \\
\hline Urban & Log of urban population rate as \% of population. & 1.849 & 0.112 & 1.541 & 2 \\
\hline Married & $\begin{array}{l}\text { Log of the rate of the married population as } \% \text { of the adult } \\
\text { population. }\end{array}$ & 1.798 & 0.030 & 1.657 & 1.841 \\
\hline Internet & $\begin{array}{l}\text { Log of the rate of total (Mobile }+ \text { fixed) broadband subscriptions as } \\
\% \text { of population. }\end{array}$ & 1.724 & 0.161 & 1.348 & 2.126 \\
\hline Phone & $\begin{array}{l}\text { Log of the rate of total (Mobile }+ \text { fixed) telephone subscriptions as \% } \\
\text { of population. }\end{array}$ & 2.095 & 0.055 & 1.913 & 2.299 \\
\hline Education & $\begin{array}{l}\text { Log of the share of bachelor, master and PhD graduates in adult } \\
\text { population. }\end{array}$ & 1.088 & 0.111 & 0.751 & 1.441 \\
\hline Literacy & Log of the literacy rate as $\%$ of the adult population. & 1.976 & 0.011 & 1.947 & 1.994 \\
\hline Crime & $\begin{array}{l}\text { Log of the number of prisoners because of specific crimes per } \\
10,000 \text { adults. }\end{array}$ & 0.981 & 0.287 & 0.118 & 1.407 \\
\hline
\end{tabular}

Notes: 1) The statistics are generated from the panel data set over the period 2011-2016 for 81 Turkish provinces. 2) All data were obtained from the Turkish Statistical Institute.

\section{Preliminary Analyses}

\subsection{Regional Financial Inclusion Inequality}

The average IFI scores of 81 Turkish provinces, as shown in Table 2, increased from 0.235 to 0.244 between 2011 and 2016. However, IFI scores did not achieve growth uniformly throughout the regions: the east and middle regions experienced generally a bigger positive change than the West (see, Fig. 3).

Fig. 3 concentrates on the natural-logarithmic variations of the IFI values in Turkish provinces ${ }^{8}$. According to the details of Fig. 3 (for In change 2011-2016), the province with the highest variation is the Muş with an increase of $57 \%$ and the eight (Muş, Kilis, Mardin, Ağrı, Iğdır, Ardahan, Bingöl and Adıyaman) of the top ten provinces in the high-change group are in the eastern of Turkey. Considering low-change group (for In change 2011-2016), five (Bolu, Burdur, Kastamonu, Bilecik and Zonguldak) of ten provinces are in the western of Turkey. From a different standpoint, the growth in the IFI values from 2011 to 2016 of three (izmir, Kocaeli and Ankara) of the top five cities is negative (Table 2). IFI values belonging to five (Siirt, Şanlıurfa, Bingöl, Ağrı and
Muş) of the last ten in Table 2 showed an increase by more than $20 \%$, and the scores of the two cities (Hakkari and Van) also increased by more than $10 \%$. If we reclassify the provinces with respect to the changes in IFI, we will see that 27 (26) of the top (last) 40 provinces in Table 2 enter the last (top) 40.

While the clustered IFI values in the first column of Fig. 2 suggest the regional IFI inequality, at first glance of Fig.3, we can observe convergence in the provincial IFI scores and so a decrease in the regional IFI inequality over time. In other words, we can see some underdeveloped provinces strive to catch up with the most developed regions in terms of financial inclusion.

We, in this section, perform two main convergence or divergence analyses ("beta" and "sigma") to verify the aforementioned catching-up process of the provincial financial inclusion in Turkey. The results of "beta" convergence analysis are reported in Table 4. The results from the System GMM Estimation and Fixed Effects Panel Model show convergence in the financial inclusion levels. According to the System GMM, provincial financial inclusion levels converged by $68 \%$ for the entire period of 2011-2016. 


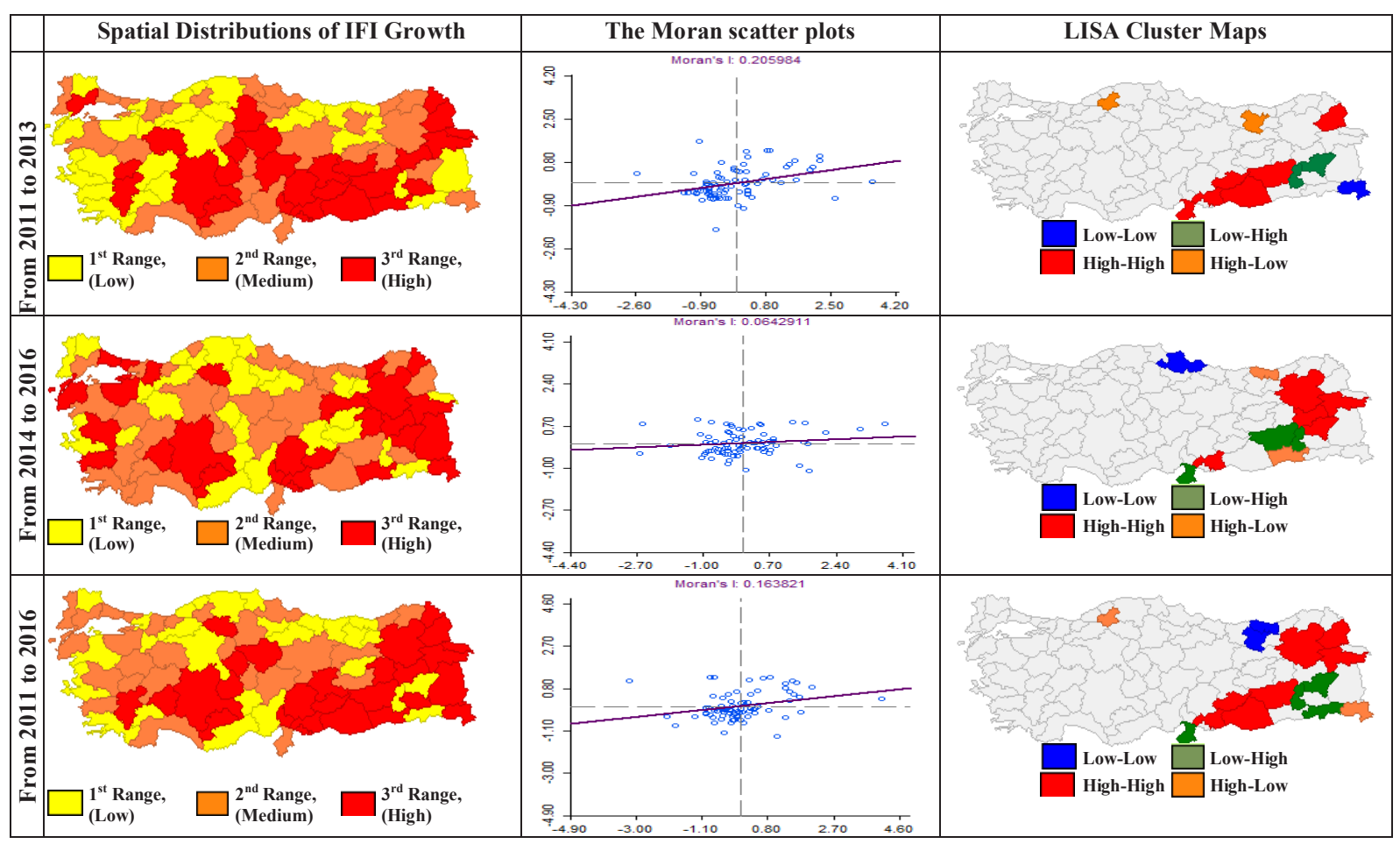

Figure 3: Geographic Distributions and Spatial Statistics of IFI Growth

Table 4: Beta and Sigma Convergences of Provincial IFI Scores

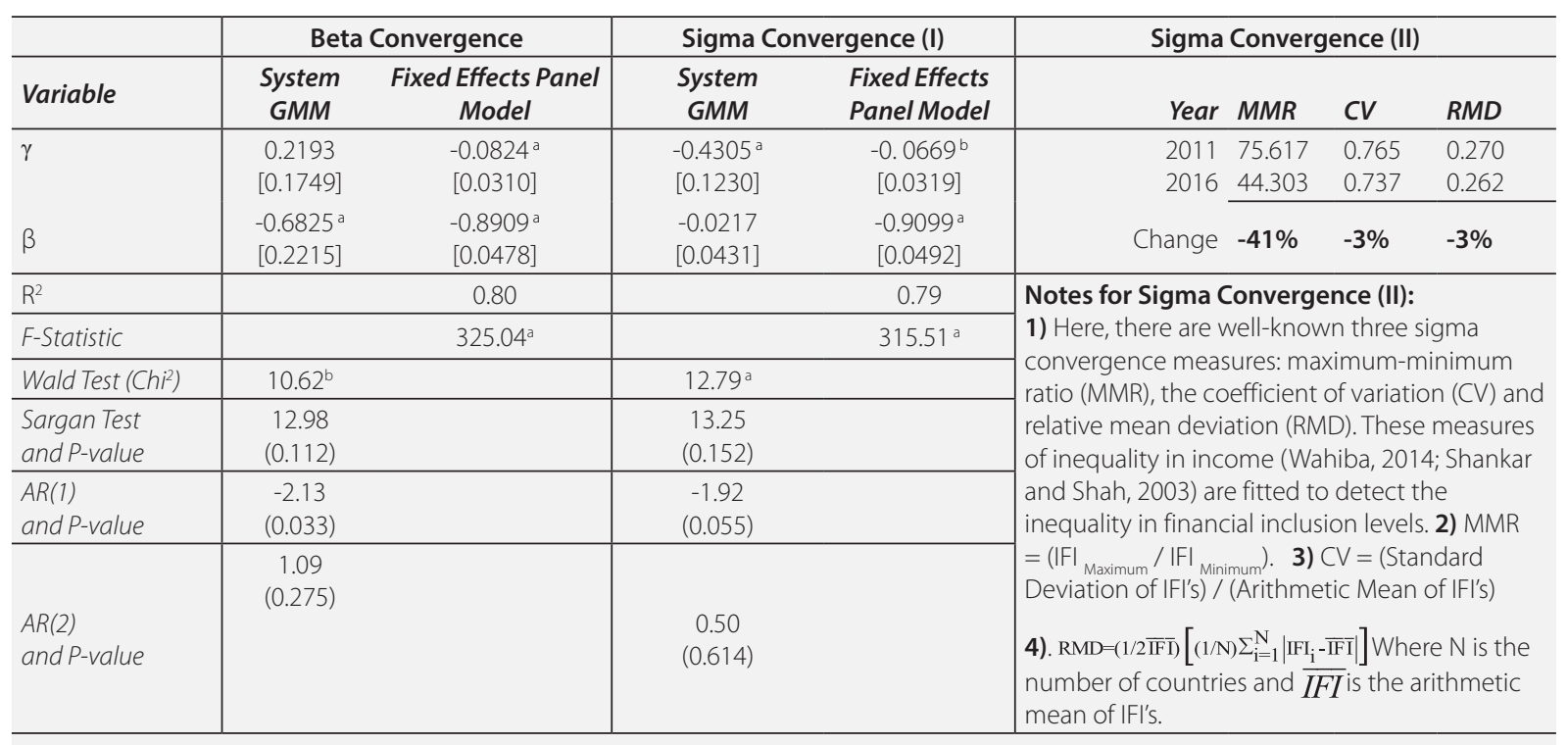

Notes: 1) Beta convergence is estimated by the equation $\mathrm{Y}_{\mathrm{i}, \mathrm{t}}=\alpha+\gamma \mathrm{Y}_{\mathrm{i}, \mathrm{t}-1}+\beta \ln \left(\mathrm{IFI}_{\mathrm{i}, \mathrm{t}-1}\right)+\mu_{\mathrm{i}, \mathrm{T}}$. Where $\mathrm{Y}$ is, $\ln \left(\mathrm{IFI}_{\mathrm{i}, \mathrm{t}} / \mathrm{IFI}_{\mathrm{i}, \mathrm{t}-1}\right) \mu$ is standard error term, $a$ is the constant term and $\beta$ is beta convergence parameter. Sigma convergence $(I)$ is estimated by the equation.

$y_{\mathrm{i}, \mathrm{t}}=\alpha+\gamma y_{\mathrm{i}, \mathrm{t}-1}+\beta \ln \left(\mathrm{IFI}_{\mathrm{i}, \mathrm{t}-1} / \overline{\mathrm{IFI}}_{\mathrm{t}-1}\right)+\mu_{\mathrm{i}, \mathrm{T}}$ Where $\mathrm{y}$ is $\left[\ln \left(\mathrm{IFI}_{\mathrm{i}, \mathrm{t}} / \overline{\mathrm{IFI}_{\mathrm{t}}}\right)-\ln \left(\mathrm{IFI}_{\mathrm{i}, \mathrm{t}-1} / \overline{\mathrm{IFI}_{\mathrm{t}-1}}\right)\right]$ and $\overline{\mathrm{IFI}_{\mathrm{t}}}$ is the arithmetic mean of IFI's in time $\mathrm{t}$. For both approaches, a statistically significant negative (positive) beta parameter supports the convergence (divergence) hypothesis. 2) For system GMM, the Sargan tests of over-identifying restrictions do not reject the $\mathrm{H}_{0}$ of the valid instruments. Also, statistically significant AR(1) and insignificant $A R(2)$ test results show that the second differences of residuals are not serially correlated while there is a first-order serial correlation. Finally, Wald test statistics confirm that all models are statistically significant. 3) ( ${ }^{a}$ and ${ }^{b}$ ) symbolize statistical significances at the $1 \%$ and $\% 5$ levels. 
As for the "sigma" convergence (I) analysis (see, Table 4), there is a provincial financial inclusion convergence for Fixed Effects Panel Model. However, for system GMM estimation, the negative beta coefficient, showing a convergence, is statistically insignificant. In spite of the fact that we cannot mention a clear sigma convergence based upon the regression analyses; the results of "sigma" convergence (II) analysis (see, Table 4) confirm the presence of provincial financial inclusion convergence. The drops in the MMR, CV and RMD, which are used as the measures of "sigma" convergence, imply the regional convergence and the reduction in inequality in provincial financial inclusion levels.

Investment incentives in Turkey may have an important role in the aforementioned convergence process in the provincial financial inclusion levels. Incentive system in Turkey aims to provide economic and social development in the less developed regions (especially, in the eastern and southeastern cities of Turkey). This purpose also helps the decreasing inequities in IFI scores because these regions are underdeveloped regions in terms of financial inclusion.

\subsection{Spatial Dependence of Provincial IFI Scores}

Global Moran's I is a frequently used coefficient in the related literature (Moran, 1950; Guillain et al., 2006; Bai et al., 2012; Lottman, 2012), and in this direction, we first calculate the Global Moran's I coefficients for both the levels and changes in the IFI scores by Eq. 9 (see, Fig. 2 and Fig. 3) to examine the existence of the spatial spillover between provincial IFI scores.

$$
I=n \frac{\sum_{i=1}^{n} \sum_{j=1}^{n} W_{i j}\left(x_{i}-\bar{x}\right)\left(x_{j}-\bar{x}\right)}{\sum_{i=1}^{n} \sum_{j=1}^{n} W_{i j} \sum_{i=1}^{n}\left(x_{i}-\bar{x}\right)^{2}}
$$

Where $\mathrm{n}$ is the number of spatial units which equals to 81 in our paper. " $x$ " is the observations of the spatial unit " $\mathrm{i}$ " an " $\mathrm{j}$ ", $\bar{x}$ is the average value of " $\mathrm{x}$ ". In this paper, " $\mathrm{W}_{\mathrm{ij}}$ " is the spatial weight matrix established according to the concept of Queen Contiguity (Lesage, 1999).
The middle column of Fig. 2 depicts the annual Moran's I coefficients from 2011 to 2016, whose values are in between 0.43 and 0.45 and statistically significant all at $1 \%$ level. These significantly positive coefficients for each year approve the existence of a strong and positive spatial spillover effect in provincial financial inclusion levels. That is to say, the IFI value of a province moves in the same direction with the IFI values of its neighbour provinces, and so IFI scores of contiguous provinces in Turkey are generally similar to each other. However, this similarity may not be valid in all provinces because Global Moran's I coefficient only summarize overall tendency. According to the Quadrant I (upper right) and III (lover left) of scatter plots in Fig. 2, IFI scores of most provinces (totally 56 ) are similar each other for all years but some provinces (totally 25) in Quadrant II (upper left) and IV (lower right) are spatial outliers and have negative spatial autocorrelation. The Moran scatter plots in Fig. 2 show the dispersions of "local" Moran I coefficients for each province and enable us more to elaborate on the spatial spillover effects. The each of six Moran scatter plots in Fig. 2 consists of four quadrants and Quadrant I and III exhibit, for each province, the presence of positive spatial spillover and regional heterogeneity (i.e. regional aggregation) in provincial IFI scores. As an example, in 2016, 22 provinces in Quadrant I (34 provinces in Quadrant III) are provinces with high (low) IFI scores surrounded by provinces with high (low) IFI scores. LISA cluster maps in Fig. 2 show only statistically significant (at $1 \%$ and $5 \%$ levels) regional heterogeneity of the provincial financial inclusion in Turkey. Cluster maps of all years illustrate that the cities in the west are the members of high aggregation region, where provinces have high IFI score together with their neighbours. However, the cities in the east are the members of LL region where cities with low IFI scores have neighbours with low scores. Manisa is a differentiated city in 2013, 2014 and 2015 because it has the lower scores $(0.231,0.234$, and 0.238 , respectively) than its neighbours with higher scores (for example, the score of Balıkesir is 0.29 in the related years).

Fig. 3 exhibits Moran's I statistics, the scatter plots of local Moran's I coefficients and LISA cluster maps of the changes in provincial IFI scores for both all periods and two sub-periods. The summary of this spatial statistics is as Table 5. 
Table 5: Summary of Spatial Statistics in Figure 3

\begin{tabular}{|c|c|c|c|}
\hline Spatial Statistics & $\begin{array}{l}\text { All Period } \\
(2011-2016)\end{array}$ & $\begin{array}{l}\text { First Sub-Period } \\
(2011-2013)\end{array}$ & $\begin{array}{l}\text { Second Sub-Period } \\
(2014-2016)\end{array}$ \\
\hline Global Moran's I & $\begin{array}{l}\text { The coefficient "I" is } 0.16 \text { at } 1 \% \\
\text { level, indicating positive spatial } \\
\text { spillover. }\end{array}$ & $\begin{array}{l}\text { The coefficient "I" is } 0.20 \text { at } 1 \% \\
\text { level, indicating positive spatial } \\
\text { spillover. }\end{array}$ & $\begin{array}{l}\text { The coefficient "I" is } 0.06 \text {, } \\
\text { indicating positive spatial } \\
\text { spillover, but statistically } \\
\text { insignificant. }\end{array}$ \\
\hline Scatter Plots & $\begin{array}{l}\text { Quadrant I and III include } \\
\text { totally } 59 \text { provinces having } \\
\text { positive spatial spillover. } \\
\text { Totally } 22 \text { cities in Quadrant } \\
\text { II and IV are spatial outliers } \\
\text { and have negative spillover. } \\
\text { These findings reveal a strong } \\
\text { regional heterogeneity. }\end{array}$ & $\begin{array}{l}\text { Quadrant I and III include totally } \\
57 \text { provinces having positive } \\
\text { spatial spillover. Totally } 24 \text { cities } \\
\text { in Quadrant II and IV are spatial } \\
\text { outliers and have negative } \\
\text { spillover. These findings reveal a } \\
\text { strong regional heterogeneity. }\end{array}$ & $\begin{array}{l}\text { Quadrant I and III include totally } \\
49 \text { provinces having positive } \\
\text { spatial spillover. Totally } 32 \text { cities } \\
\text { in Quadrant II and IV are spatial } \\
\text { outliers and have negative } \\
\text { spillover. These findings reveal a } \\
\text { strong regional heterogeneity. }\end{array}$ \\
\hline Cluster Maps & $\begin{array}{l}\text { HH clusters are mainly located } \\
\text { in the east of Turkey (at } \\
\text { statistically significant at 1\% } \\
\text { and 5\% levels) }\end{array}$ & $\begin{array}{l}\text { HH clusters are mainly located in } \\
\text { the east of Turkey (at statistically } \\
\text { significant at } 1 \% \text { and } 5 \% \text { levels). }\end{array}$ & $\begin{array}{l}\text { HH clusters are mainly located in } \\
\text { the east of Turkey (at statistically } \\
\text { significant at } 1 \% \text { and } 5 \% \text { levels). }\end{array}$ \\
\hline
\end{tabular}

Considering the explanations in Table 5, it is distinguished that the change in provincial IFI values is affected in the same direction by the change in IFI values of its adjacent provinces and the eastern cities contribute to the decrement of disparities in provincial IFI in Turkey.

\section{Estimation Results}

\subsection{Spatial Panel Model Selection}

In this subsection, specification tests are applied to choose the best suitable spatial panel model, because we thus far have demonstrated strong spatial spillover effects and heterogeneities for both the levels and changes of provincial IFI scores in Turkey. After identifying spatial spillover effects in the data, choosing of the best suitable model is crucial to avoid biased results and estimates. Following LeSage and Pace (2009), the SDM in Eq. 7 is first estimated and then Specification Test (chi2) is used to determine which model is the best fit for our panel data (Belotti, Hughes \& Mortari, 2016). If the results of the specification tests indicate $\theta=0$, the best model is SLM. If the results of the tests indicate $\theta=$ $-\rho \beta$, the best model is SEM. If the results indicate $\theta \neq 0$ and $\theta \neq-\rho \beta$, the best suitable model is SDM. The results of specification tests given in Table 6 reveal that the best appropriate spatial panel model is SDM (or SACM) as compared to SEM and SLM. For our data set, SDM is also more feasible than the SACM in accordance with the smallest information criteria "BIC" and "AIC" (see, Table 6).

Another choice favoured to determine the best model is to use the Lagrange multiplier tests (Anselin, Le Gallo, and Jayet, 2008). These tests are used to make a choice among the SACM, SLM and SEM models. The null hypothesis of the LM test for SEM states that there is no spatial autocorrelation in the error term $(\lambda=0)$ and the null hypothesis of the LM test for SLM states that there is no spatial autocorrelation in the dependent variable $(\rho=0)$. Table 7 presents the LM test results and its robust forms, which strongly reject the above two null hypotheses (that is, the terms $\lambda$ and $\rho$ are different from 0 ). The results of the LM tests in Table 7 reveal that the best appropriate spatial panel model is SACM (or SDM) as compared to SEM and SLM. However, as we said before, SDM is more feasible than the SACM for our data in accordance with the smallest information criteria "BIC" and "AIC" (see, Table 6). 
Table 6: Results of Specification Tests (chi2)

\begin{tabular}{|c|c|c|c|c|c|}
\hline & I & II & III & IV & V \\
\hline \multicolumn{6}{|l|}{ A-Results of the SDM; } \\
\hline$R^{2}$ & 0.6317 & 0.6109 & 0.6436 & 0.6277 & 0.6146 \\
\hline$\rho$ & $0.2120^{a}$ & $0.2058^{a}$ & $0.2176^{\mathbf{a}}$ & $0.1960^{a}$ & $0.2307^{a}$ \\
\hline \multicolumn{6}{|l|}{$B$ - Results of $H_{0}$ for SLM } \\
\hline $\mathrm{Chi}^{2}$ & $34.79^{a}$ & $40.12^{a}$ & $31.69^{a}$ & $33.63^{a}$ & $46.29^{a}$ \\
\hline $\mathrm{H}_{0}:$ & Reject & Reject & Reject & Reject & Reject \\
\hline \multicolumn{6}{|l|}{ C-Results of $H_{0}$ for SEM } \\
\hline $\mathrm{Chi}^{2}$ & $34.69^{a}$ & $39.40^{\mathbf{a}}$ & $31.81^{a}$ & $33.98^{a}$ & $44.46^{a}$ \\
\hline $\mathrm{H}_{0}:$ & Reject & Reject & Reject & Reject & Reject \\
\hline Selected Model & $S D M$ & $S D M$ & $S D M$ & $S D M$ & $S D M$ \\
\hline AIC for SDM & -2276.852 & -2281.783 & -2286.779 & -2282.457 & -2296.152 \\
\hline AIC for SACM & -2264.571 & -2264.661 & -2274.957 & -2270.655 & -2272.519 \\
\hline
\end{tabular}

Notes: Section A shows the statistics of SDM in Eq. 7 and results of hypotheses $H_{0}: \theta=0$ for Spatial Lagged Model in section $B$ and also results of $H_{0}: \theta=-\rho \beta$ for Spatial Error Model in section $C$ are reported. If both $\mathrm{H}_{0}$ is not accepted, the best model is the Spatial Durbin Model due to the lowest AIC and BIC.

Table 7: Results of Specification Tests (LM)

\begin{tabular}{|c|c|c|c|c|c|}
\hline & I & II & III & IV & V \\
\hline \multicolumn{6}{|l|}{ Results of $\mathrm{H}_{0}$ for SEM } \\
\hline LM & $37.812^{a}$ & $47.896^{a}$ & $58.309^{a}$ & $57.614^{a}$ & $83.662^{a}$ \\
\hline LM robust & $54.994^{\mathrm{a}}$ & $61.860^{a}$ & $74.970^{a}$ & $74.019^{a}$ & $104.871^{a}$ \\
\hline $\mathrm{H}_{0}:$ & Reject & Reject & Reject & Reject & Reject \\
\hline \multicolumn{6}{|l|}{ Results of $\mathrm{H}_{0}$ for SLM } \\
\hline LM & $25.719^{a}$ & $11.899^{a}$ & $13.539^{a}$ & $13.337^{a}$ & $15.972^{\mathbf{a}}$ \\
\hline LM robust & $42.900^{\mathbf{a}}$ & $25.862^{\mathbf{a}}$ & $30.201^{a}$ & $29.741^{\mathbf{a}}$ & $37.181^{a}$ \\
\hline $\mathrm{H}_{0}:$ & Reject & Reject & Reject & Reject & Reject \\
\hline Selected Model & SDM & SDM & SDM & SDM & SDM \\
\hline
\end{tabular}

Notes: The table shows the results on spatial dependence in OLS regression. $\left({ }^{\mathrm{a}}, \mathrm{b}\right.$ and $\left.\mathrm{c}\right)$ symbolizes statistical significance at $1 \%, 5 \%$ and $10 \%$ levels, respectively.

"Gdp", “Poverty", “Unemployment", "Inflation” and "Tourism" variables in this paper could not be estimated in the same model due to the potential multicollinearity problem. Therefore, these variables are estimated in the separate models. In Table 6 and 7, column I provides the test results for the regression equation with "Gdp", column II with "Poverty", column III with "Unemploy- ment", column IV with "Inflation" and column V with "Tourism". For each regression equation, the best spatial panel model is SDM.

In this paper, three types of SDM have been employed. One of those is the pure SDM in Eq.7 which is selected by LM tests and is used due to the detection of strong spatial spillover effect and heterogeneity in 
the dependent variable. One type is the dynamic spatial Durbin model (DSDM) in which the time-lagged values of the variables $\log \left(\mathrm{IFI}_{\mathrm{it}}\right)$ are included as the independent variables into the pure SDM in Eq.7 (Debarsy, Ertur and LeSage, 2012; Arcuri, Brunetto and Levratto, 2019). DSDM can solve two important issues: (i) the serial dependence between observations of each unit in time and (ii) the presence of unobservable time-invariant specific factors (Arcuri, Brunetto and Levratto, 2019) and is generally estimated by Maximum Likelihood (ML) approach or Quasi-Maximum Likelihood (QML) estimator (Lee and Yu, 2010). ML (or QML) estimator provides more consistent and effective estimates than the Least Square approach. However, the ML can also lead to inconsistent estimates for the models with the endogeneity problems. To cope with the possible endogeneity problems ${ }^{9}$ in the models, we also estimated the DSDM via System Generalized Method of Moments estimator (SYS-GMM) proposed by Arellano and Bover (1995) and later developed by Blundell and Bond (1998).

\subsection{Model Results and Discussion}

Table 8 shows the results of all SDM to display the impact of selected factors on provincial IFI scores. According to all SDM's, the spatially lagged dependent variable $(\rho)$ is significantly positive at $1 \%$ level. This finding evinces that our spatial panel models have strictly endogeneity problems because of the significant spatially lagged dependent variables " $\mathrm{W}_{\mathrm{ij}} \log \left(\mathrm{IF|}_{\mathrm{it}}\right)$ " as an explanatory variable. Because coefficient " $\rho$ " denotes that the financial inclusion levels of the neighbouring provinces affect the IFI score of the province in the same direction. Accordingly, the financial inclusion level of that province also has an influence on the IFI score of another neighbouring province. In brief, the IFI score of a province is interdependence with the IFI score of other contiguous provinces. Additionally, there may be a relationship between dependent variable IFI and other independent variables (such as GDP and inflation) in two-way, as with the variable " $\mathrm{W}_{\mathrm{ij}} \log \left(\mathrm{IF} \mathrm{I}_{\mathrm{it}}\right)$ ". For example, the increasing financial inclusion could affect positively GDP of the provinces as well as financial inclusion is affected GDP. In addition to these, our dynamic models may have also the endogeneity problems through a possible correlation between the time-lagged values of the variable "log $\left(\mathrm{IFI}_{\mathrm{it}}\right)$ " as an independent variable and the error term.

In the light of all the facts mentioned above, we think that the choicest estimation technique is the DSDM via SYS-GMM. This spatial panel technique, which presents the results of the estimations obtained by the SYS-GMM, allows us to gain more robust and reliable estimates by dealing with the crucial problems such as regional heterogeneities, spatial dependences and endogeneity issues. For this reason, only findings related to the DSDM via SYS-GMM will be interpreted. However, Table 8 renders estimation results for pure SDM and DSDM too in order that the results can be checked by readers.

According to the SYS-GMM results in all columns of Table 8, the time-lagged IFI scores have a positive and significant impact on the current IFI scores. This autoregressive parameter values lie between 0.42 and 0.56 and indicate that there is a regional conditional convergence ${ }^{10}$, even as the impact of neighbouring IFI values on IFI is controlled. Conditional convergence implies that cities converge towards the same IFI values and IFI values are becoming more similar across regions. This situation is consistent with our previous findings. 


\section{Table 8: Empirical Results}

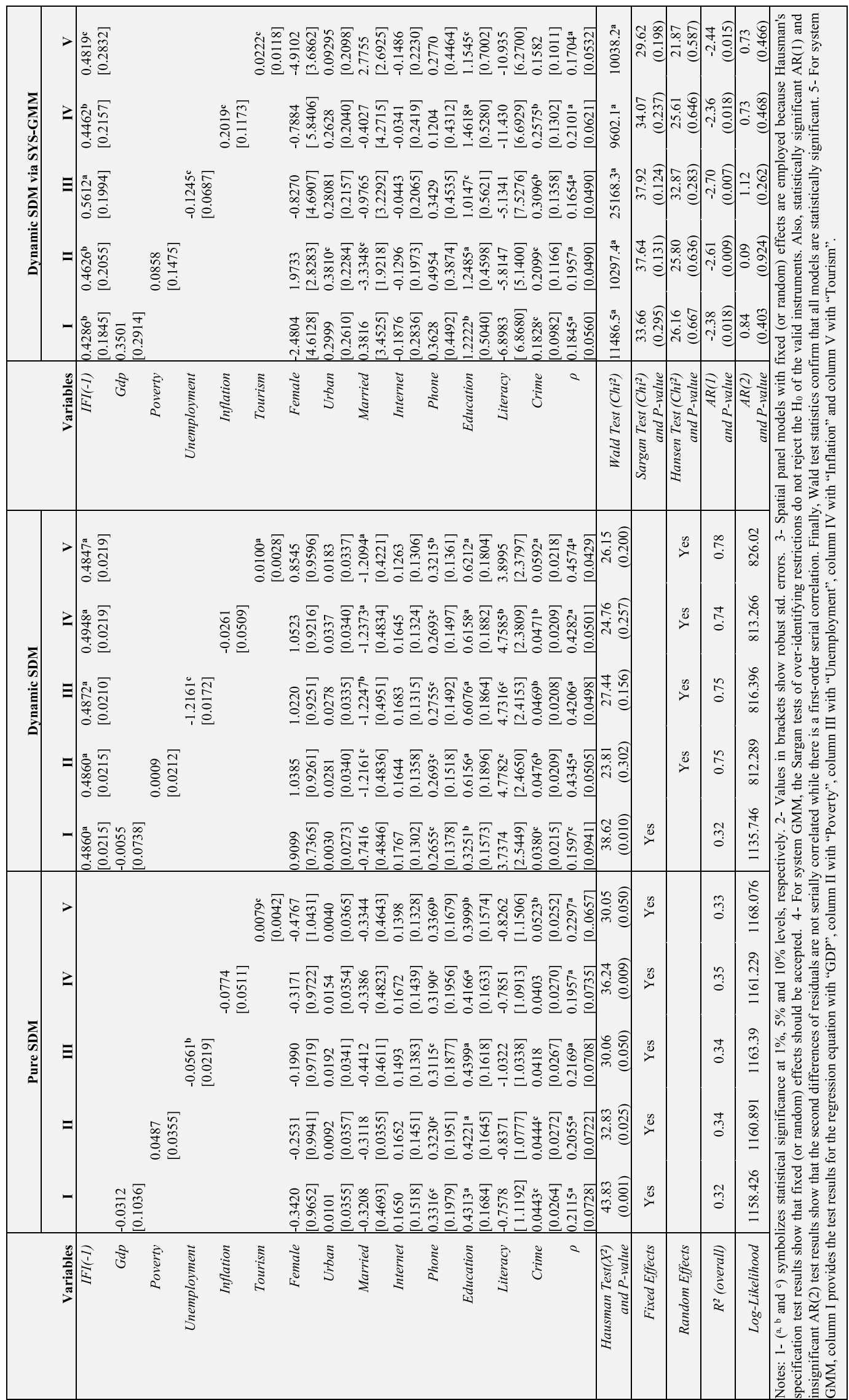


The coefficients of the spatially lagged dependent variable, which lie between 0.16 and 0.21 , reveal the significant impact of neighbouring IFI scores on the provincial financial inclusion levels. Coefficient " $\rho$ ", which show the developments in the provincial IFI scores are influenced by their spatial interdependence, also proves that provincial financial inclusion convergence is not only a "temporal" process but also a "spatial" process (Bouayad-Agha and Vedrine, 2010).

Variables of "unemployment" with coefficient -0.124 and "married" with coefficient -3.334 have the negative and significant effects on provincial IFI scores in Turkey. The negative effect means that financial inclusion has grown in provinces experiencing a decrease in unemployment and the married population rate. The reduction in the unemployment rate may allow the individuals to interact more with the banks by increasing both the income and the expenses of them. Thus, it is expected that the decrease in the unemployment rate will have a positive impact on IFI scores. Variable of "married" becomes statistically significant after controlling for the variable of "poverty". The results obtained on the proportion of the married population may be explained by the economic violence against women that exists in Turkey. Economic violence is the use of economic resources and money as the tools of sanctions, threats and control over women. Economic violence behaviours includes situations such as not to allow the married woman to work, to confiscate her salary, income and possessions, to give away little money, to take away the freedom of spending money, not to give information about family savings, income and expenses, to decide on economic matters concerning the family without taking the opinion of the woman, to refuse to accept her contribution to the home economy (Fawole, 2008). In a study conducted on 300 married women who applied to the psychiatry policlinic of Cumhuriyet University, it was determined that $32 \%$ of women aged 16-29 years were exposed to economic violence. (Kocacık and Doğan, 2006). In addition, the probability of leaving a job is higher for women in Turkey for the reasons such as marriage and children (Gürkan and Coşar, 2009). This being the case, the increases in the rates of marriage have the effect of decreasing the provincial IFI scores because of the social structure of Turkey (i.e., because of the exclusion of married women in Turkey from the financial system).

With respect to the variables with positive influence, we see that the variables of "urban" (0.381), "tourism" (0.022), "inflation" (0.201), "education" (1.014 - 1.461) and "crime" (0.158 - 0.309) have an impact on IFI. More clearly, if the urban population rate, the number of overnight stays of foreign tourists, inflation rate, the rate of the population with a university or more degree and crime rate in a province increase, the IFI score of that province will increase. Increases in the accommodation of tourists may have increased provincial IFI scores by extending the facilities such as bank branches and ATMs facilitating access to the financial system. The findings on crime rates support what we say about it. As we said previously, higher crime rate promotes the usage of the payment products (i.e. financial inclusion) and decreases cash preference. Arun \& Kamath (2015) emphasize that lower crime rate hinders the usage of the payment products (i.e. financial inclusion) and increases cash preferences. The education level, as one of the demand factors, is likely to greatly impact the access to and usage of finance (Wang \& Guan, 2017). In this direction, we detect that the well-educated people positively influences the IFI scores of the provinces. Variable of "urban" becomes statistically significant at the $10 \%$ level after controlling for the variable of "poverty", which implies that an average increase of $1 \%$ in the urban population rates leads to a raise of $0.3 \%$ in the IFI score. As for the variable of inflation, although one study (Evans and Adeoye, 2016) concluded that inflation has an insignificant impact on financial inclusion, this paper concluded that an increase in the general level of prices raises the levels of the provincial IFI. In general, the investment decisions are negatively affected during the inflationary periods due to the high discount (or interest) rates. High interest rates also affect credit demands negatively. In spite of this, when interest rates are raised, people tend to choose deposits as their investment asset, since it has a lower risk (Setiawan, Wati and Putu, 2019). At this point, the reason for our results on inflation may be those who want to protect the purchasing power of money. These people may have increased provincial IFI scores by utilizing the banking products and services more in order to invest in TL or foreign currency deposits (especially, inflation-indexed deposits) or to buy gold.

Although the variable of "phone" is not significant for GMM, it was found to be significant in the other two models. The positive effect of this variable on IFI indicates that an increase in the rate of total (Mobile + fixed) telephone subscriptions is associated with a boost in IFI scores of Turkish provinces. Telephone infrastructure is among the necessary elements for the use of telephone banking. Telephone banking makes it possible to benefit quickly and easily from almost all 
of the services provided by a bank branch, regardless of time and place. In this case, the increases in the number of telephone users in the provinces may have (i) directed the community to the telephone banking, (ii) incorporated into the financial system and (iii) affected IFI scores positively. Similar to our study, Kendall, Mylenko, and Ponce (2010) use fixed line density as a measure of the development of physical infrastructure and found that it is positively associated with financial inclusion.

\section{Conclusion and Discussion}

There are empirical studies which investigate the factors leading to the financial inclusion of countries. However few papers have examined thoroughly the effect of spatial interactions on local financial inclusion levels. In this paper, we compute IFI scores representing financial inclusion levels of 81 provinces in Turkey - which is an emerging economy and a Muslim candidate country to EU - for each year by using panel data between 2011 and 2016 and then detected the determinants of provincial financial inclusion levels by benefiting from spatial regression models via System GMM estimation. The reason why this paper adopted spatial models is that the existence of spatial spillover and heterogeneity in provincial financial inclusion was detected by utilizing LISA analyze and Global Moran's I statistic.

According the results of DSDM via SYS-GMM, which cope with the possible endogeneity problems and holds in check spatial connections both between dependent factors and between independent variables, "unemployment", "urban", "tourism", "married", "education", "inflation" and "crime" variables have a strong impact on provincial financial inclusion levels positively or negatively. However, the variable of "phone" has a weak and positive effect on the provincial IFI scores. We also confirmed the convergence in the distribution of provincial financial inclusion by examining the spatial patterns of IFI scores for the period 2011-2016. Considering results on convergence, the eastern cities contribute to the decrement of disparities in provincial IFI in Turkey.

Our findings on the factors affecting provincial financial inclusion level provide useful information for policymakers and enable us to make some implications. For instance, to contribute to their provincial IFI scores and so provide a more convergence in provincial IFI scores, local administrators of the provinces with low IFI scores should try to augment the number of married women joining in the financial system. For this, firstly economic violence should be prevented, the educational level of society should be increased, employment opportunities of married women should be increased and working conditions should be facilitated. Of course, all of these should also be done across the country. Apart from these, the tourism potentials of the provinces should be determined and the number of provinces that attract tourists should be increased by making necessary studies. Such an effort can also contribute positively to the provincial IFI scores by reducing unemployment. In addition, the cities with low financial inclusion level should improve the level of education (especially, financial literacy) of their society, especially women, students and rural residents. Because women, students, the unemployed and rural residents are the most disadvantaged in both financial literacy and access to financial services (Güngen, 2017). Local administrators can cooperate with the relevant departments of universities to increase the financial literacy level.

Considering LISA analyze and Global Moran's I statistic, we found that IFI value of a province moves in the same direction with the IFI values of its neighbour provinces and IFI scores of contiguous provinces in Turkey are generally similar each other in other words there is regional heterogeneity of the provincial financial inclusion in Turkey. As we have noted before, IFI scores of cities are influenced not only by their own characteristics but also by the characteristics of surrounding cities. According to these findings, we can highlight two issues. Firstly, being border to any of the advanced cities will make easier the solving the problems about financial inclusion for provinces with low IFI scores. Second, decisions of decision makers (such as governor or mayor) influence not only financial inclusion level of their own province but also the levels of surrounding provinces. Therefore, developing collaboration between the border cities may provide more financial inclusion across Turkey. This is another policy implication of this paper.

Finally, because of the insufficient level of studies done on this issue in emerging economies, assiduous researchers can focus attention on how spatial interactions can be used to increase provincial financial inclusion levels in other emerging countries. Also, researchers can investigate the effect of digital swindle as a novel variable on IFI. Lastly, for Turkey, it may also be interesting to examine the interactions of IFI with the variables such as GDP and Inflation by using Panel VAR models. 


\section{References}

Al-Hussainy, E., Beck, T., Demirguc-Kunt, A., \& Zia, B. (2008). Household use of financial services. World Bank Working Paper, 502-516.

Andrianaivo, M., \& Kpodar, K. (2011). ICT, financial inclusion, and growth evidence from African countries. International Monetary Fund (No. 11-73).

Anselin, L., Le Gallo, J., \& Jayet, H. (2008). Spatial Panel Econometrics. In L. Mátyás, \& P. Sevestre (Eds.), The econometrics of panel data (pp. 625-660). Berlin: Springer-Verlag.

Arcuri, G., Brunetto, M., \& Levratto, N. (2019). Spatial patterns and determinants of firm exit: an empirical analysis on France. The Annals of Regional Science, 62(1), 99-118.

Arellano, M., \& Bover, O. (1995). Another look at the instrumental variable estimation of error-components models. Journal of econometrics, 68(1), 29-51.

Arora, R.U. (2014). Access to finance: an empirical analysis. The European Journal of Development Research, 26 (5), 798-814.

Arun, T., \& Kamath, R. (2015). Financial inclusion: Policies and practices. IIMB Management Review, 27(4), 267287.

Bai, C. E., Ma, H., \& Pan, W. (2012). Spatial spillover and regional economic growth in China. China Economic Review, 23(4), 982-990. http://dx.doi.org/10.1016/j. chieco.2012.04.016.

Beck, T., Levine, R., \& Levkov, A. (2007). Big bad banks? The impact of US branch deregulation on income distribution. The World Bank, NBER Working Paper Series (13299).

Belotti, F., Hughes, G., \& Mortari, A. P. (2016). Spatial panel data models using Stata. CEIS Research Papers No.373, 14(5), 1-40.

Blundell, R., \& Bond, S. (1998). Initial conditions and moment restrictions in dynamic panel data models. Journal of econometrics, 87(1), 115-143.

Bouayad-Agha, S., \& Vedrine, L. (2010). Estimation strategies for a spatial dynamic panel using GMM. A new approach to the convergence issue of European regions. Spatial Economic Analysis, 5(2), 205-227.

Bozkurt, I., Karakuş, R., \&Yildiz, M. (2018). Spatial Determinants of Financial Inclusion over Time. Journal of International Development, 30(8), 1474-1504.

Bruhn, M., \& Love, I. (2014). The real impact of improved access to finance: Evidence from Mexico. The Journal of Finance, 69(3), 1347-1376.
Carrillo-Hidalgo, I., \& Pulido-Fernández, J. I. (2019). Is the financing of tourism by international financial institutions inclusive? A proposal for measurement. Current Issues in Tourism, 22(3), 330-356.

Caselli, F., Esquivel, G., \& Lefort, F. (1996). Reopening the Convergence Debate: A New Look at Cross-Country Growth Empirics. Journal of Economic Growth, 1, 363-389.

Chattopadhyay, S.K. (2011). Financial Inclusion in India: A case study of West Bengal. RBI Working Paper Series (DEPR), 8/2011.

Chithra, N., \& Selvam, M. (2013). Determinants of financial inclusion: An empirical study on the inter-state variations in India. Retrieved from, SSRN: http:// dx.doi.org/10.2139/ssrn.2296096

Dabla-Norris, M. E., Ji, Y., Townsend, R., \& Unsal, D. F. (2015). Identifying constraints to financial inclusion and their impact on GDP and inequality: A structural framework for policy. IMFWorking Paper (No. 15-22). International Monetary Fund, Washington.

Debarsy, N., Ertur, C., \& LeSage, J. P. (2012). Interpreting dynamic space-time panel data models. Statistical Methodology, 9(1-2), 158-171.

Demirguc-Kunt, A., Klapper, L., \& Randall, D. (2013). Islamic finance and financial inclusion: measuring use of and demand for formal financial services among Muslim adults. (Policy Research Working Paper No. 6642). TheWorld Bank, Washington, DC.

Demirgüç-Kunt, A., Klapper, L., Singer, D., \& Van Oudheusden, P. (2015). The Global Findex Database 2014. Measuring Financial Inclusion Around the world (Policy Research Working Paper No. 7255). The World Bank, Washington, DC.

Elhorst, J.P. (2010). Spatial panel data models. In Handbook of Applied Spatial Analysis. Edited by Fischer Manfred, and Getis Arthur. New York: Springer.

Evans, O., \& Adeoye, B. (2016). Determinants of Financial Inclusion in Africa: A Dynamic Panel Data Approach. University of Mauritius Research Journal, 22, 310-336.

Fawole, O. I. (2008). Economic violence to women and girls: is it receiving the necessary attention?. Trauma, Violence, \& Abuse, 9(3), 167-177.

Fingleton, B., \& Le Gallo, J. (2008). Estimating spatial models with endogenous variables, a spatial lag and spatially dependent disturbances: Finite sample properties. Papers in Regional Science, 87(3), 319339. 
Fungáčová, Z., \& Weill, L. (2015). Understanding financial inclusion in China. China Economic Review, 34, 196-206.

Gupte, R., Venkataramani, B., \& Gupta, D. (2012). Computation of financial inclusion index for India. Procedia-Social and Behavioral Sciences, 37, 133-149.

Guillain, R., Le Gallo, J., \& Boiteux-Orain, C. (2006). Changes in spatial and sectoral patterns of employment in Ile-de-France, 1978-97. Urban studies, 43(11), 2075-2098.http://dx.doi. org/10.1080/00420980600945203.

Güngen, A. R. (2018). Financial inclusion and policy-making: Strategy, campaigns and microcredit a la Turca. New Political Economy, 23(3), 331-347.

Gürkan, Ö. C., \& Coşar, F. (2009). Ekonomik şiddetin kadın yaşamındaki etkileri. Maltepe Üniversitesi Hemşirelik Bilim ve Sanatı Dergisi, 2(3), 124-129.

Honohan, P. (2008). Cross-country variation in household access to financial services. Journal of Banking \& Finance, 32(11), 2493-2500.

Kairiza, T., Kiprono, P., \& Magadzire, V. (2017). Gender differences in financial inclusion amongst entrepreneurs in Zimbabwe. Small Business Economics, 48(1), 259-272.

Kendall, J., Mylenko, N., \& Ponce, A. (2010). Measuring Financial Access around the World. Policy Research Working Paper, No 5253 (Washington: World Bank).

Kocacik, F., \& Dogan, O. (2006). Domestic violence against women in Sivas, Turkey: survey study. Croatian medical journal, 47(5), 742-749.

Kumar, N. (2013). Financial inclusion and its determinants: evidence from state level empirical analysis in India. Journal of Financial Economic Policy, 5 (1), 4-19.

Lee, L. F., \& Yu, J. (2010). Some recent developments in spatial panel data models. Regional Science and Urban Economics, 40(5), 255-271.

LeSage, J.P. (1999). Spatial Econometrics: Regional Research Institute. West Virginia University.

LeSage, J.P., \& Pace, R.K. (2009). Introduction to Spatial Econometrics. Taylor \& Francis.

Lottmann, F. (2012). Spatial dependencies in German matching functions. Regional Science and Urban Economics, 42 (1-2), 27-41. http://dx.doi.org/10.1016/j. regsciurbeco.2011.04.007.

Marr, A., \& Schmied, J. (2013) Financial inclusion and poverty: The case of Peru. In: 3rd European Research Conference on Microfinance, 10-12 Jun 2013, University of Agder, Kristiansand, Norway.
Mohieldin, M., lqbal, Z., Rostom, A., \& Fu, X. (2011). The role of Islamic finance in enhancing financial inclusion in Organization of Islamic Cooperation (OIC) countries. The World Bank, Islamic Economics and Finance Working Group (WPS5920).

Moran, P. A. (1950). Notes on continuous stochastic phenomena. Biometrika, 37(1/2), 17-23. http:// dx.doi.org/10.2307/2332142.

Nwafor, M. C., \& Yomi, A.I. (2018). The Nexus between Financial Inclusion and Economic Growth: Evidence from Nigeria. International Journal of Science and Innovation in Social Science, 2(4), 143-149.

Sahay, R., Cihak, M., N'Diaye, P., Barajas, A., Mitra, S., Kyobe, A., Nian Mooi, Y., \& Reza Yousefi, S. (2015). Financialinclusion:can itmeet multiple macroeconomic goals?. IMF staff discussion note 15/17. International Monetary Fund, Washington.

Sahoo, A. K., Pradhan, B. B., \& Sahu, N. C. (2017). Determinants of Financial Inclusion in Tribal Districts of Odisha: An Empirical Investigation. Social Change, 47(1), 45-64.

Sarma, M. (2008). Index of financial inclusion. Working Paper No.215, Indian Council for Research on International Economic Relations.

Setiawan, C., Wati, K., \& Putu, N. (2019). Factors Affecting the Performance of Sharia Equity Funds in Indonesia. Iranian Journal of Management Studies, 12(4), 481-508.

Schmied, J., \& Marr, A. (2017). Financial inclusion and poverty: The case of Peru. Regional and Sectoral Economic Studies, 16(2), 1-26.

Siddik, M. N. A., Sun, G., \& Kabiraj, S. (2015). Financial inclusion and its determinants: A study of Bangladesh. Indian Journal of Finance, 9(6), 7-29.

Swamy, V. (2014). Financial inclusion, gender dimension, and economic impact on poor households. World Development, 56, 1-15.

Qiang X, Kan Tao. (2017). The Measurement of China's Index of Financial Inclusion and Its Relationship with Poverty Aueviation: Analysis Based on Provincial Data. Journal of Central China Normal University 56 (6): 40-51.

Uddin, A., Chowdhury, M. A. F., \& Islam, M. N. (2017). Determinants Of Financial Inclusion In Bangladesh: Dynamic Gmm \& Quantile Regression Approach. The Journal of Developing Areas, 51(2), 221-237.

Wang, X., \& Guan, J. (2017). Financial inclusion: measurement, spatial effects and influencing factors. Applied Economics, 49(18), 1751-1762. 
Yadav, P., \& Sharma, A. K. (2016). Financial inclusion in India: an application of TOPSIS. Humanomics, 32(3), 328-351.

Yorulmaz, R. (2013). Construction of a regional financial inclusion index in Turkey. Journal of BRSA Banking and Financial Markets, 7(1), 79-101.
Zins, A., \& Weill, L. (2016). The determinants of financial inclusion in Africa. Review of Development Finance, 6(1), 46-57. 


\section{APPENDIX}

\section{Appendix A: Summary of Indicators Composing the IFI (Data from 81 Turkish Provinces)}

\begin{tabular}{|c|c|c|c|c|c|c|}
\hline Dimension & Indicator & Max & Min & $\begin{array}{l}\text { Std. } \\
\text { Dev. }\end{array}$ & CV & $\mathbf{W}_{\mathbf{i j}}$ \\
\hline \multirow{6}{*}{$\begin{array}{l}\text { "Access" } \\
\text { Dimension } \\
\text { (2011) }\end{array}$} & $\begin{array}{l}\text { Number of accounts at the financial institutions per adults } \\
\text { age } 15+\end{array}$ & 3.37 & 0.91 & 0.2527 & 0.4894 & 0.0947 \\
\hline & $\begin{array}{l}\text { The proportion of active customers having internet } \\
\text { banking account to adults age } 15+\end{array}$ & 0.25 & 0.05 & 0.2435 & 0.6911 & 0.1337 \\
\hline & Number of ATMs per 100,000 adults age 15+ & 114.34 & 16.74 & 0.2558 & 0.6336 & 0.1226 \\
\hline & $\begin{array}{l}\text { Number of commercial bank branches per 100,000 adults } \\
\text { age 15+ }\end{array}$ & 27.19 & 4.78 & 0.2240 & 0.5345 & 0.1034 \\
\hline & Number of ATMs per $1,000 \mathrm{~km}^{2}$ & 1554.08 & 4.06 & 0.2124 & 1.4285 & 0.2764 \\
\hline & Number of commercial bank branches per 1,000 km² & 545.23 & 1.40 & 0.2103 & & 0.2690 \\
\hline \multirow{5}{*}{$\begin{array}{l}\text { “Usage" } \\
\text { Dimension } \\
\text { (2011) }\end{array}$} & $\begin{array}{l}\text { Outstanding deposits with commercial banks per adults } \\
15+\end{array}$ & 29674.59 & 1251.79 & 0.2451 & 0.7400 & 0.2477 \\
\hline & Outstanding deposits with commercial banks (\% of GDP) & 85.47 & 9.00 & 0.2502 & 0.6360 & 0.2129 \\
\hline & Outstanding loans from commercial banks per adults $15+$ & 24110.96 & 1707.81 & 0.2188 & 0.6217 & 0.2081 \\
\hline & Outstanding loans from commercial banks (\% of GDP) & 59.98 & 12.28 & 0.2141 & 0.4439 & 0.1486 \\
\hline & $\begin{array}{l}\text { The proportion of checks used to make payments to adults } \\
\text { age } 15+\end{array}$ & 0.46 & 0.12 & 0.2299 & 0.5460 & 0.1828 \\
\hline \multirow{6}{*}{$\begin{array}{l}\text { "Access" } \\
\text { Dimension } \\
\text { (2012) }\end{array}$} & $\begin{array}{l}\text { Number of accounts at the financial institutions per adults } \\
\text { age } 15+\end{array}$ & 3.18 & 0.92 & 0.2454 & 0.4856 & 0.0949 \\
\hline & $\begin{array}{l}\text { The proportion of active customers having internet } \\
\text { banking account to adults age } 15+\end{array}$ & 0.29 & 0.06 & 0.2415 & 0.6495 & 0.1269 \\
\hline & Number of ATMs per 100,000 adults age 15+ & 119.90 & 17.38 & 0.2539 & 0.6294 & 0.1229 \\
\hline & $\begin{array}{l}\text { Number of commercial bank branches per 100,000 adults } \\
\text { age 15+ }\end{array}$ & 27.63 & 5.16 & 0.2220 & 0.5351 & 0.1045 \\
\hline & Number of ATMs per 1,000 km² & 1733.64 & 4.06 & 0.2133 & 1.4156 & 0.2765 \\
\hline & Number of commercial bank branches per 1,000 km² $^{2}$ & 565.43 & 1.48 & 0.2097 & 1.4038 & 0.2742 \\
\hline \multirow{5}{*}{$\begin{array}{l}\text { “Usage" } \\
\text { Dimension } \\
(2012)\end{array}$} & $\begin{array}{l}\text { Outstanding deposits with commercial banks per adults } \\
15+\end{array}$ & 32519.75 & 1218.65 & 0.2394 & 0.7146 & 0.2339 \\
\hline & Outstanding deposits with commercial banks (\% of GDP) & 82.45 & 7.51 & 0.2304 & 0.6110 & 0.2000 \\
\hline & Outstanding loans from commercial banks per adults $15+$ & 28343.94 & 1692.73 & 0.2102 & 0.5754 & 0.1884 \\
\hline & Outstanding loans from commercial banks (\% of GDP) & 67.43 & 11.94 & 0.2643 & 0.6076 & 0.1989 \\
\hline & $\begin{array}{l}\text { The proportion of checks used to make payments to adults } \\
\text { age } 15+\end{array}$ & 0.46 & 0.12 & 0.2299 & 0.5460 & 0.1787 \\
\hline \multirow{6}{*}{$\begin{array}{l}\text { "Access" } \\
\text { Dimension } \\
\text { (2013) }\end{array}$} & $\begin{array}{l}\text { Number of accounts at the financial institutions per adults } \\
\text { age } 15+\end{array}$ & 3.20 & 0.97 & 0.2473 & 0.4783 & 0.0950 \\
\hline & $\begin{array}{l}\text { The proportion of active customers having internet } \\
\text { banking account to adults age } 15+\end{array}$ & 0.32 & 0.08 & 0.2409 & 0.6304 & 0.1253 \\
\hline & Number of ATMs per 100,000 adults age 15+ & 133.65 & 21.24 & 0.2626 & 0.6280 & 0.1248 \\
\hline & $\begin{array}{l}\text { Number of commercial bank branches per 100,000 adults } \\
\text { age 15+ }\end{array}$ & 28.55 & 5.11 & 0.2165 & 0.4885 & 0.0971 \\
\hline & Number of ATMs per $1,000 \mathrm{~km}^{2}$ & 1946.88 & 5.15 & 0.2165 & 1.4159 & 0.2814 \\
\hline & Number of commercial bank branches per $1,000 \mathrm{~km}^{2}$ & 599.31 & 1.48 & 0.2069 & 1.3910 & 0.2764 \\
\hline \multirow{5}{*}{$\begin{array}{l}\text { "Usage" } \\
\text { Dimension } \\
\text { (2013) }\end{array}$} & $\begin{array}{l}\text { Outstanding deposits with commercial banks per adults } \\
15+\end{array}$ & 39246.65 & 1664.75 & 0.2489 & 0.7399 & 0.2363 \\
\hline & Outstanding deposits with commercial banks (\% of GDP) & 84.90 & 9.99 & 0.2610 & 0.6608 & 0.2110 \\
\hline & Outstanding loans from commercial banks per adults $15+$ & 36602.22 & 2353.34 & 0.2275 & 0.6655 & 0.2125 \\
\hline & Outstanding loans from commercial banks (\% of GDP) & 75.18 & 14.64 & 0.2138 & 0.5193 & 0.1658 \\
\hline & $\begin{array}{l}\text { The proportion of checks used to make payments to adults } \\
\text { age } 15+\end{array}$ & 0.46 & 0.12 & 0.2299 & 0.5460 & 0.1744 \\
\hline
\end{tabular}




\begin{tabular}{|c|c|c|c|c|c|c|}
\hline \multirow{6}{*}{$\begin{array}{l}\text { "Access" } \\
\text { Dimension } \\
(2014)\end{array}$} & \multicolumn{4}{|l|}{ Number of accounts at the financial institutions per adults } & 0.4750 & 0.0965 \\
\hline & $\begin{array}{l}\text { The proportion of active customers having internet } \\
\text { banking account to adults age } 15+\end{array}$ & 0.36 & 0.09 & 0.2406 & 0.5790 & 0.1176 \\
\hline & Number of ATMs per 100,000 adults age 15+ & 144.45 & 22.56 & 0.2610 & 0.5998 & 0.1219 \\
\hline & $\begin{array}{l}\text { Number of commercial bank branches per 100,000 adults } \\
\text { age 15+ }\end{array}$ & 28.29 & 5.45 & 0.2246 & 0.4946 & 0.1005 \\
\hline & Number of ATMs per $1,000 \mathrm{~km}^{2}$ & 2082.76 & 5.30 & 0.2162 & 1.3885 & 0.2821 \\
\hline & Number of commercial bank branches per $1,000 \mathrm{~km}^{2}$ & 603.93 & 1.48 & 0.2061 & 1.3847 & 0.2814 \\
\hline \multirow{5}{*}{$\begin{array}{l}\text { “Usage” } \\
\text { Dimension } \\
\text { (2014) }\end{array}$} & $\begin{array}{l}\text { Outstanding deposits with commercial banks per adults } \\
15+\end{array}$ & 44216.28 & 1747.88 & 0.2477 & 0.7225 & 0.2285 \\
\hline & Outstanding deposits with commercial banks (\% of GDP) & 79.68 & 10.65 & 0.2620 & 0.6761 & 0.2138 \\
\hline & Outstanding loans from commercial banks per adults $15+$ & 44121.35 & 2855.14 & 0.2220 & 0.6702 & 0.2119 \\
\hline & Outstanding loans from commercial banks (\% of GDP) & 78.59 & 16.38 & 0.2133 & 0.5474 & 0.1731 \\
\hline & $\begin{array}{l}\text { The proportion of checks used to make payments to adults } \\
\text { age } 15+\end{array}$ & 0.46 & 0.12 & 0.2299 & 0.5460 & 0.1727 \\
\hline \multirow{6}{*}{$\begin{array}{l}\text { "Access" } \\
\text { Dimension } \\
(2015)\end{array}$} & $\begin{array}{l}\text { Number of accounts at the financial institutions per adults } \\
\text { age } 15+\end{array}$ & 3.21 & 1.03 & 0.2640 & 0.4745 & 0.0951 \\
\hline & $\begin{array}{l}\text { The proportion of active customers having internet } \\
\text { banking account to adults age } 15+\end{array}$ & 0.84 & 0.11 & 0.2166 & 0.6423 & 0.1288 \\
\hline & Number of ATMs per 100,000 adults age 15+ & 148.06 & 25.22 & 0.2683 & 0.6085 & 0.1220 \\
\hline & $\begin{array}{l}\text { Number of commercial bank branches per 100,000 adults } \\
\text { age 15+ }\end{array}$ & 27.16 & 5.82 & 0.2305 & 0.4988 & 0.1000 \\
\hline & Number of ATMs per 1,000 km² & 2159.35 & 5.83 & 0.2190 & 1.3872 & 0.2781 \\
\hline & Number of commercial bank branches per $1,000 \mathrm{~km}^{2}$ & 593.53 & 1.60 & 0.2076 & 1.3762 & 0.2759 \\
\hline \multirow{5}{*}{$\begin{array}{l}\text { "Usage" } \\
\text { Dimension } \\
\text { (2015) }\end{array}$} & $\begin{array}{l}\text { Outstanding deposits with commercial banks per adults } \\
15+\end{array}$ & 50466.59 & 2121.66 & 0.2416 & 0.7164 & 0.2238 \\
\hline & Outstanding deposits with commercial banks (\% of GDP) & 81.30 & 11.66 & 0.2563 & 0.6731 & 0.2103 \\
\hline & Outstanding loans from commercial banks per adults $15+$ & 51795.93 & 3158.10 & 0.2227 & 0.6843 & 0.2137 \\
\hline & Outstanding loans from commercial banks (\% of GDP) & 93.63 & 16.49 & 0.2025 & 0.5876 & 0.1835 \\
\hline & $\begin{array}{l}\text { The proportion of checks used to make payments to adults } \\
\text { age } 15+\end{array}$ & 0.58 & 0.15 & 0.2258 & 0.5401 & 0.1687 \\
\hline \multirow{6}{*}{$\begin{array}{l}\text { "Access" } \\
\text { Dimension } \\
(2016)\end{array}$} & $\begin{array}{l}\text { Number of accounts at the financial institutions per adults } \\
\text { age } 15+\end{array}$ & 3.29 & 1.10 & 0.2612 & 0.4643 & 0.0938 \\
\hline & $\begin{array}{l}\text { The proportion of active customers having internet } \\
\text { banking account to adults age } 15+\end{array}$ & 0.51 & 0.12 & 0.2450 & 0.5759 & 0.1163 \\
\hline & Number of ATMs per 100,000 adults age 15+ & 148.12 & 25.70 & 0.2726 & 0.6018 & 0.1216 \\
\hline & $\begin{array}{l}\text { Number of commercial bank branches per 100,000 adults } \\
\text { age } 15+\end{array}$ & 25.46 & 6.56 & 0.2374 & 0.5491 & 0.1109 \\
\hline & Number of ATMs per $1,000 \mathrm{~km}^{2}$ & 2160.32 & 6.05 & 0.2210 & 1.3841 & 0.2796 \\
\hline & Number of commercial bank branches per $1,000 \mathrm{~km}^{2}$ & 563.70 & 1.67 & 0.2081 & 1.3754 & 0.2778 \\
\hline \multirow{5}{*}{$\begin{array}{l}\text { "Usage" } \\
\text { Dimension } \\
\text { (2016) }\end{array}$} & $\begin{array}{l}\text { Outstanding deposits with commercial banks per adults } \\
15+\end{array}$ & 60186.64 & 2475.78 & 0.2362 & 0.7067 & 0.2241 \\
\hline & Outstanding deposits with commercial banks (\% of GDP) & 88.06 & 11.77 & 0.2533 & 0.6269 & 0.1988 \\
\hline & Outstanding loans from commercial banks per adults $15+$ & 61459.78 & 3502.25 & 0.2207 & 0.7176 & 0.2276 \\
\hline & Outstanding loans from commercial banks (\% of GDP) & 92.70 & 15.79 & 0.2017 & 0.6180 & 0.1960 \\
\hline & $\begin{array}{l}\text { The proportion of checks used to make payments to adults } \\
\text { age } 15+\end{array}$ & 0.53 & 0.11 & 0.2111 & 0.4839 & 0.1535 \\
\hline
\end{tabular}

Notes:1) "Max." and "Min." values are raw data for each indicator. After performing the transformation by Eq. 2, max=1 and min=0 for each indicator. 2) "Std. Dev." is standard deviation of transformed values of the indicator j. 3) CV (Coefficient of Variation $)=($ Std. Dev.) / (Mean of transformed values of the indicator j). 4) "W"value represents the results of Eq. 3. 


\section{Endnotes}

1 These issues are inequality, poverty, empowerment of women, disadvantaged and poor people's incomes and employment opportunities, and financial stability and also its probable consequences on these issues are inherently positive (see, Sahay et. al., 2015; Qiang \& Kan, 2017; Bruhn \& Love, 2014; Swamy, 2014).

2 As a secular country, the majority population of Turkey is Muslim according to the an official website of the European Union (https:// eacea.ec.europa.eu/national-policies/eurydice/content/population-demographic-situation-languages-and-religions-103_en)

3 Turkey's level of financial inclusion is lower than the financial inclusion level of 22 member states of the European Union. (Bozkurt, Karakuş and Yıldız, 2017).

$4 \quad$ Financial Inclusion has also been widely accepted as the panacea for the poverty and the impetus for the growth and development (Gupte, Venkataramani and Gupta, 2012).

5 The "Access" and "Usage" dimension indexes here are the summary indices assessing the outreach of financial services and reflecting how routinely and typically financial services used (Bozkurt, Karakuş \& Yıldız, 2018).

6 In this paper, quite a lot of variables were used both for calculating IFI scores and for determining the factors affecting IFI. Our analysis period is limited to 2016 because when we started working, many of these variables were not available after 2016.

7 In first column at Fig. 2, that shows the quantile maps of IFI, cities are divided into three groups depending on the IFI scores in Table 2. The 1 st range (lower quantile) is composed of cities in the range of 0.012-0.14 IFI score, countries in the 2 nd range (medium quantile) is in the range of 0.14-0.24 score and countries in the 3rd range (high quantile) is in the range of 0.26-0.94 score in 2011. For 2012, 1 st range: 0.02-0.14, 2nd range: 0.14-0.24 and 3rd range: 0.25-0.93. For 2013, 1st range: 0.01-0.14, 2nd range: 0.14-0.25 and 3rd range: 0.25-0.94. For 2014, 1st range: 0.01-0.15, 2nd range: 0.15-0.25 and 3rd range: 0.25-0.95. For 2015, 1st range: 0.01-0.15, 2nd range: 0.15-0.25 and 3rd range: $0.25-0.96$. For 2016 , 1st range: 0.02 , 2nd range: 0.15-0.25 and 3rd range: 0.25-0.97. Other spatial statistics at Fig. 2 will be mentioned later.

8 In first column at Fig. 3, that shows the quantile maps of the changes in IFI scores, cities are divided into three groups by the logarithmic changes of IFI scores in Table 2. For the period 2011-2013, 1st group: -0.15 - -0.015, 2nd group: -0.013 - 0.039, and 3rd group: $0.04-0.26$. For the period 2014-2016, 1st group: -0.17 - -0.023, 2nd group: -0.023 - 0.193, and 3rd group: 0.23-0.25. For the period 2011-2016, 1st group: $-0.37--0.009$, 2nd group: $-0.004-0.070$, and 3rd group: $0.07-0.57$. Other spatial statistics at Fig. 3 will be mentioned later.

9 This problem is usually ignored in spatial econometrics (Fingleton and Le Gallo, 2008).

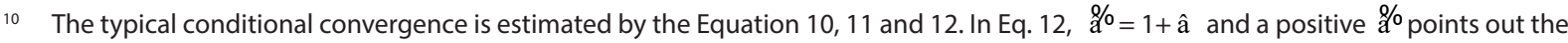
conditional convergence (See, Caselli, Esquivel and Lefort, 1996; Bouayad-Agha and Vedrine, 2010).

$$
\begin{aligned}
& \ln \left(I F I_{i, t} / I F I_{i, t-1}\right)=\alpha+\beta \ln \left(I F I_{i, t-1}\right)+\sum_{k=1}^{K} \beta_{k} X_{k i t}+\mu_{i, t} \\
& \ln \left(I F I_{i, t}\right)-\ln \left(I F I_{i, t-1}\right)=\alpha+\beta \ln \left(I F I_{i, t-1}\right)+\sum_{k=1}^{K} \beta_{k} X_{k i t}+\mu_{i, t} \\
& \ln \left(\text { IFI }_{i, t}\right)=\alpha+\beta^{\circ} \ln \left(I F I_{i, t-1}\right)+\sum_{k=1}^{K} \beta_{k} X_{k i t}+\mu_{i, t}
\end{aligned}
$$

